\title{
6 Product market structures
}

\author{
Katarzyna Filipowicz, Tomasz Tokarski \\ and Titus Ferenc
}

\subsection{Introduction}

This chapter is a continuation of the analyses carried out in Chapters 3-5. Chapter 3 presents and discusses the structural changes in the product stream and investments in Poland and Ukraine in macroeconomic terms. Chapters 4 and 5 began a series of meso-economic analyses. The division of a complex, multidimensional and dynamic structure, that is the national economy into smaller elements such as regions and sectors of regional economies, permits a better understanding of the ongoing changes in space and its economic structure.

The next parts of this chapter describe changes in the gross value added in the following sectors of the economy: agriculture, industry, construction and services in Polish voivodeships (2004-2015) and in Ukrainian oblasts (20042016). In the conducted regional analyses, these voivodeships and oblasts were divided into groups according to the same criteria as in Chapters 4 and 5. The data used in this chapter come from the Local Data Bank, Statistics Poland, (GUS) ${ }^{1}$ and the State Statistics Service of Ukraine (ДССУ). ${ }^{2}$

The analyses conducted in this chapter concern both the absolute and relative potential of various sectors of the regional economy. The absolute potential of these sectors is measured by the gross value added of individual sectors in voivodeships and oblasts, while the relative potential is the share of the gross value added in a given sector in the gross value added of four major sectors of the region's economy.

\subsection{Sector structure of the product market in Poland}

\subsubsection{Added value in agriculture}

Figure 6.1 presents the gross value added in agriculture in voivodeship groups in 2004-2015. The shape of their trajectory indicates that the value added in agriculture has fluctuated significantly in all groups of voivodeships throughout the entire research period. The course of the trajectory on the graph is probably the result of many factors, the most important of which (in the context of the agricultural sector) being climate fluctuations 


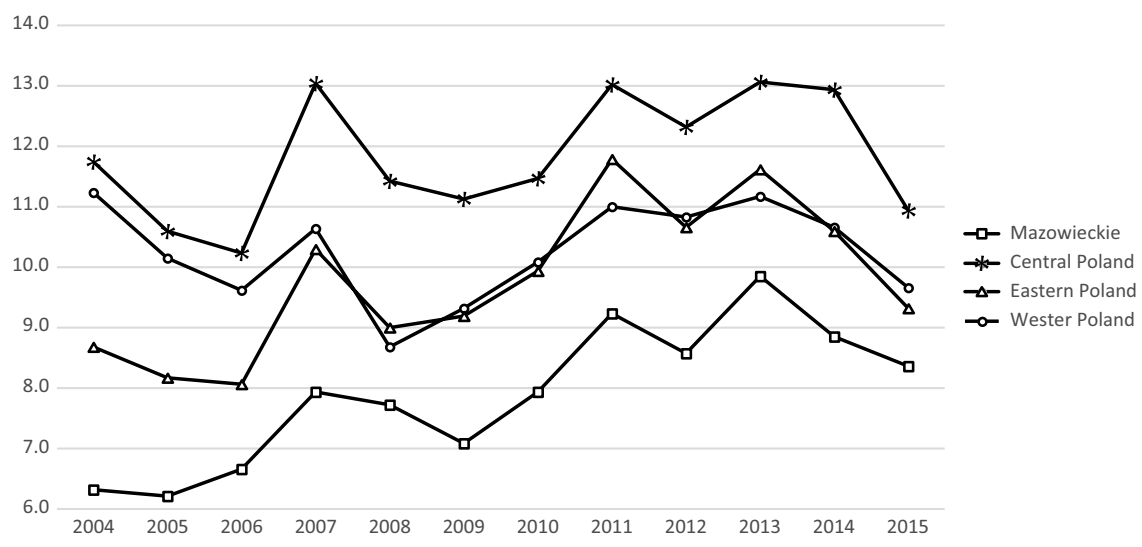

Figure 6.1 Gross value added in agriculture in voivodeship groups in 2004-2015 (PLN billion, according to 2015 prices).

Source: Our own estimates based on: https://bdl.stat.gov.pl/BDL/start (access: 2019-12-30).

and agricultural policy. It is worth noting that the agricultural potential of eastern Poland oscillated in the range of 8.1-11.8 billion PLN and was comparable or lower than the potential of western Poland (9.5-12.4 billion PLN) or central Poland (9.4-12.0 billion PLN). The Mazowieckie Voivodeship had the lowest added value in agriculture (6.2-9.2 billion PLN). In addition, the value added in agriculture increased in the Mazowieckie Voivodeship (by $32 \%$ ) and in the voivodeships of eastern Poland (by 7\%) in 2015 compared to 2004; in the other two groups there was a decrease in the value of this variable in the years under consideration.

On average, in the years 2004-2015, the highest absolute values of the variable under consideration were recorded in the following voivodeships: Mazowieckie (7.9 billion PLN), Wielkopolskie (5.7 billion PLN) and Łódzkie (3.24 billion PLN). In turn, the lowest values were observed in the following voivodeships: Lubuskie (1.08 billion PLN), Opolskie (1.07 billion PLN) and Podkarpackie (1.00 billion PLN, see Map 6.1). The low added value in agriculture in the Lubuskie and Opolskie voivodeships was probably associated with the low demographic potential of these voivodeships.

Figure 6.2 shows the share of gross value added in agriculture (in gross value added in all sectors of the economy) in groups of voivodeships. The share of the agricultural sector in GVA was falling in every group of voivodeships. The largest decrease was recorded in the group of voivodeships of western Poland (by approx. 2\% points), then in central Poland (approx. $1 \%$ point). The voivodeships of eastern Poland had the highest share of this sector in the generated gross value added (from 5.2\% in 2004 to $3.9 \%$ in 2015). In turn, the share of the agricultural sector was the lowest in the voivodeships of central Poland (in 2004 it was 2.7\%, while in 2015 it was only 1.7\%). 


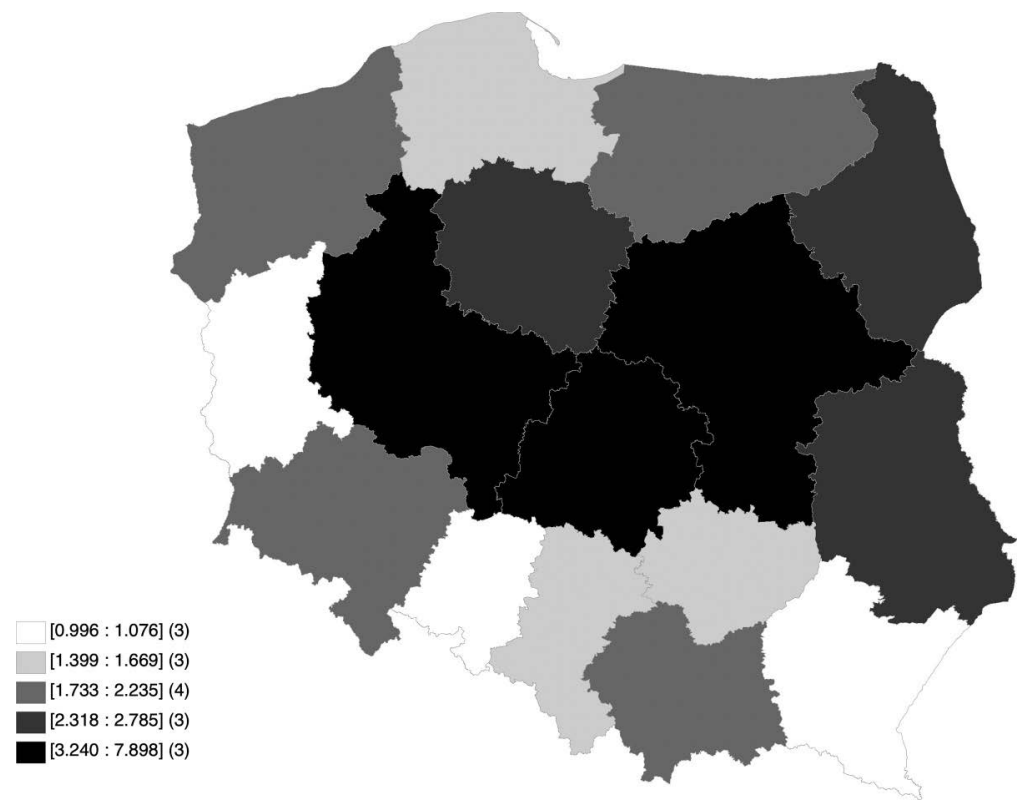

Map 6.1 Gross value added in agriculture in voivodeships in 2004-2015 (PLN billion, according to 2015 prices).

Source: Our own estimates based on: https://bdl.stat.gov.pl/BDL/start (access: 2019-12-30).

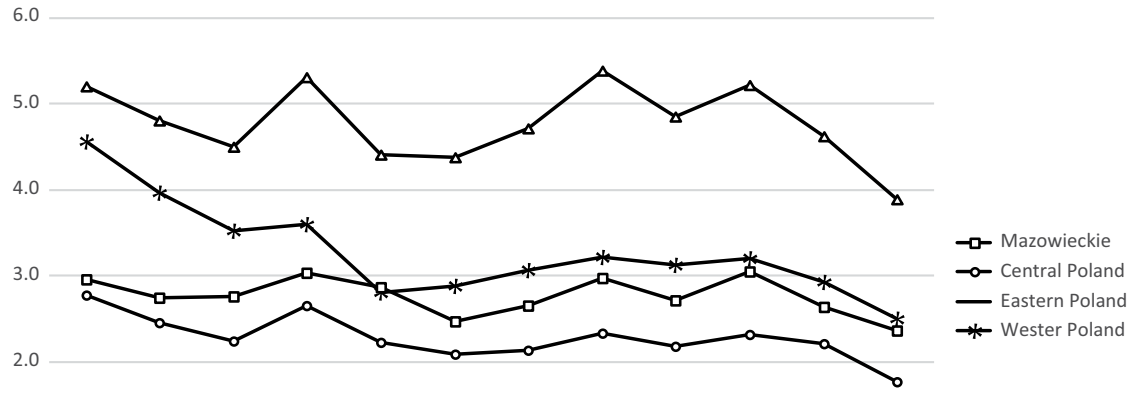

1.0

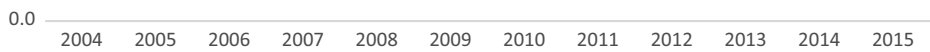

Figure 6.2 Share of gross value added in agriculture in voivodeship groups in 2004$2015(\%)$.

Source: Our own estimates based on: https://bdl.stat.gov.pl/BDL/start (access: 2019-12-30). 


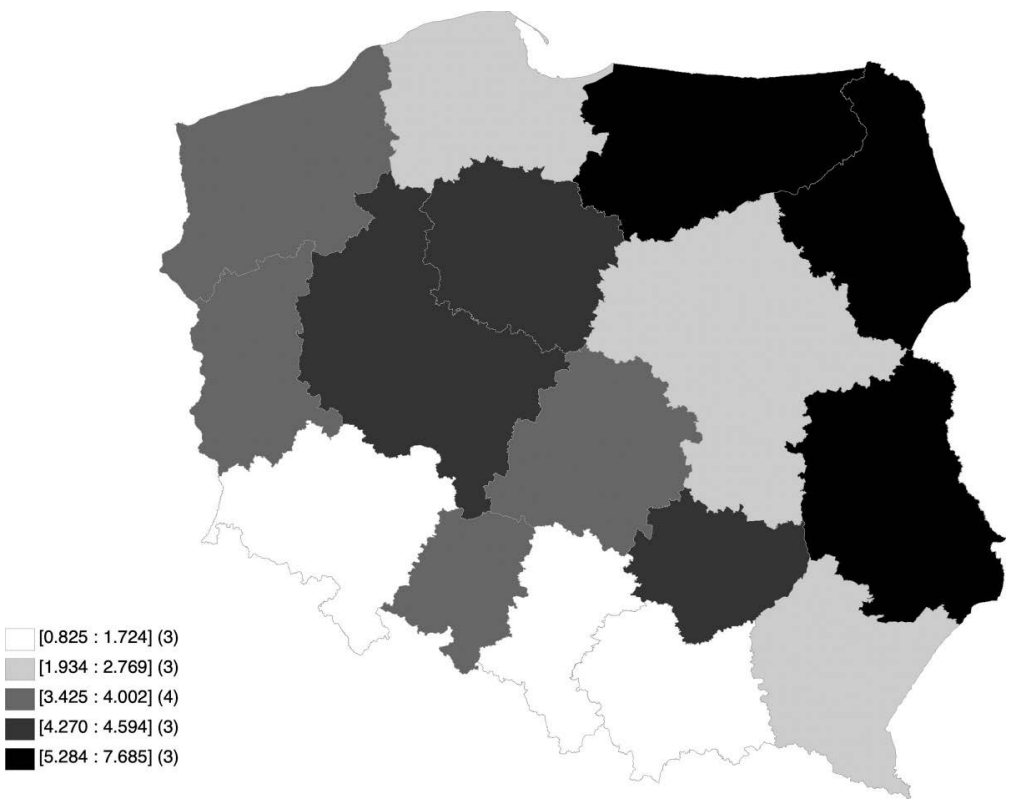

Map 6.2 Share of gross value added in agriculture in voivodeships on average in 2004-2015 (\%).

Source: Our own estimates based on: https://bdl.stat.gov.pl/BDL/start (access: 2019-12-30).

The average share of gross value added in agriculture in Poland in the years 2004-2015 was 3.0\%, so for the entire economy this sector was rather marginal. Nevertheless, there are significant differences in the importance of this sector on the level of individual voivodeships. The highest share of gross value added in agriculture was found in the following voivodeships: Podlaskie (7.7\%), Warmińsko-Mazurskie (6.2\%) and Lubelskie (5.3\%). In turn, the agricultural sector had the least significance in the generated gross value added in the following voivodeships: Małopolskie (1.7\%), Dolnośląskie $(1.6 \%)$ and Śląskie $(0.8 \%$, i.e., over seven times less than in Podlaskie, see also Map 6.2).

\subsubsection{Added value in industry}

Figure 6.3 shows the gross value added in industry in voivodeship groups. It can be observed that in the years 2004-2015, in all groups of voivodeships there was an increase in gross value added in industry. The largest increase was recorded in the Mazowieckie Voivodeship and in the voivodeships of western Poland (an increase of approx. 78\% in 2015, compared to 2004). The value added in industry is a procyclical variable; in all groups of voivodeships there was a decrease in the growth rate after 2008, that is, during the global financial crisis. Throughout the entire analyzed period, the highest 


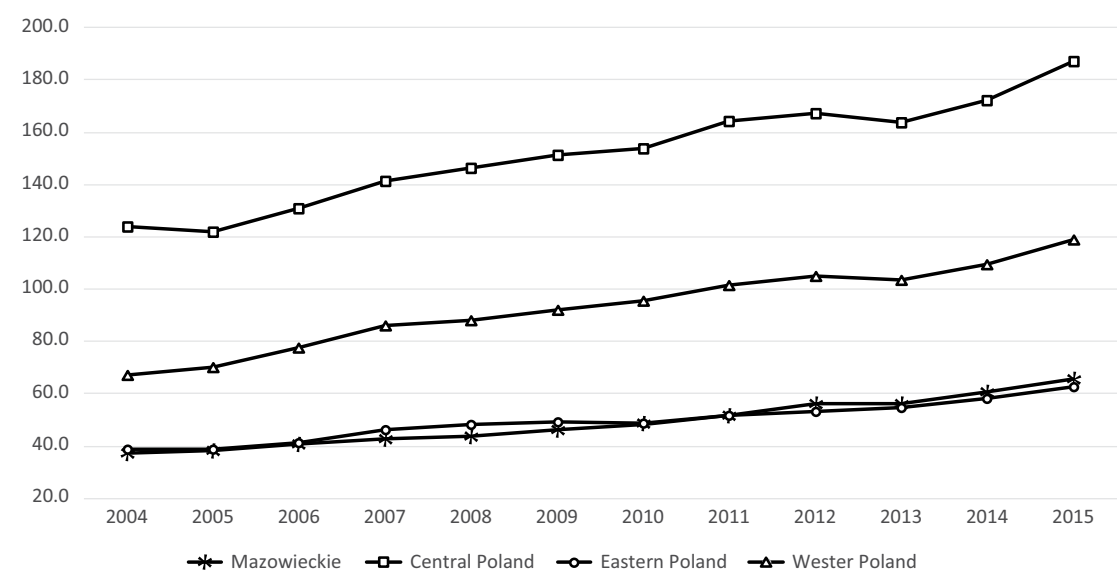

Figure 6.3 Gross value added in industry in voivodeship groups in 2004-2015 (PLN billion, according to 2015 prices).

Source: Our own estimates based on: https://bdl.stat.gov.pl/BDL/start (access: 2019-12-30).

value added in industry was recorded in the voivodeships of central Poland (PLN 114.6-175 billion). In addition, the potential of industry located in the five eastern Polish voivodeships (PLN 38.6-62.9 billion) was comparable to the potential of the industrial sector in the Mazowieckie Voivodeship (PLN $37.0-65.8$ billion).

On average, in the years 2004-2015 the highest value added in industry was recorded in the following voivodeships: Śląskie (PLN 59.9 billion), Mazowieckie (PLN 49.0 billion) and Dolnośląskie (PLN 37.7 billion). The lowest values were recorded in the following voivodeships: Opolskie (PLN 9.0 billion), Świętokrzyskie (PLN 8.8 billion) and Podlaskie (PLN 6.2 billion, see Map 6.3).

Figure 6.4 presents the share of gross value added in industry in voivodeship groups. The shape of all trajectories is similar, but one can see a slight decrease in these shares after 2008 (associated with the global financial crisis) and then, from 2013, a renewed increase in the importance of this sector in all groups of voivodeships. When comparing 2015 to 2004, an increase in the share of gross value added in industry in all groups can be observed, with the largest increase in the variable considered being recorded in the provinces of western Poland (by 3.9\% points) and eastern Poland (by $3.2 \%$ points). The industrial sector was of the greatest importance for the provinces of western Poland and central Poland. The shares of this sector in 2004-2015 in these groups changed in the range of $27.3-31.2 \%$. In the voivodeships of eastern Poland, the level of the feature considered fluctuated between $22.9 \%$ and $26.3 \%$. The lowest share of gross value added in 


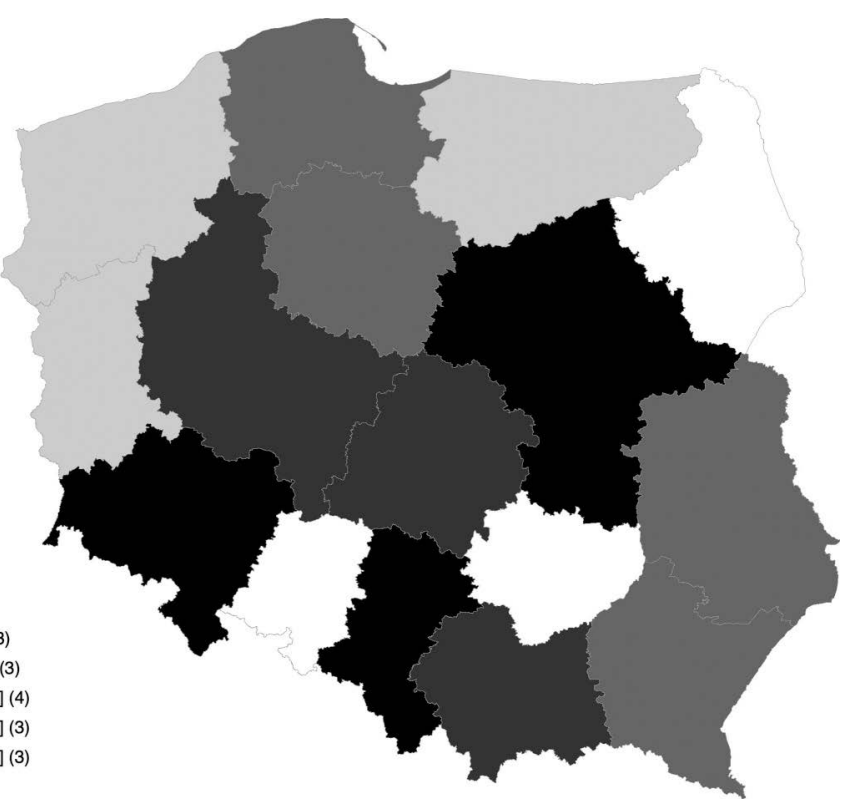

Map 6.3 Gross value added in industry in voivodeships in 2004-2015 (PLN billion, according to 2015 prices).

Source: Our own estimates based on: https://bdl.stat.gov.pl/BDL/start (access: 2019-12-30).

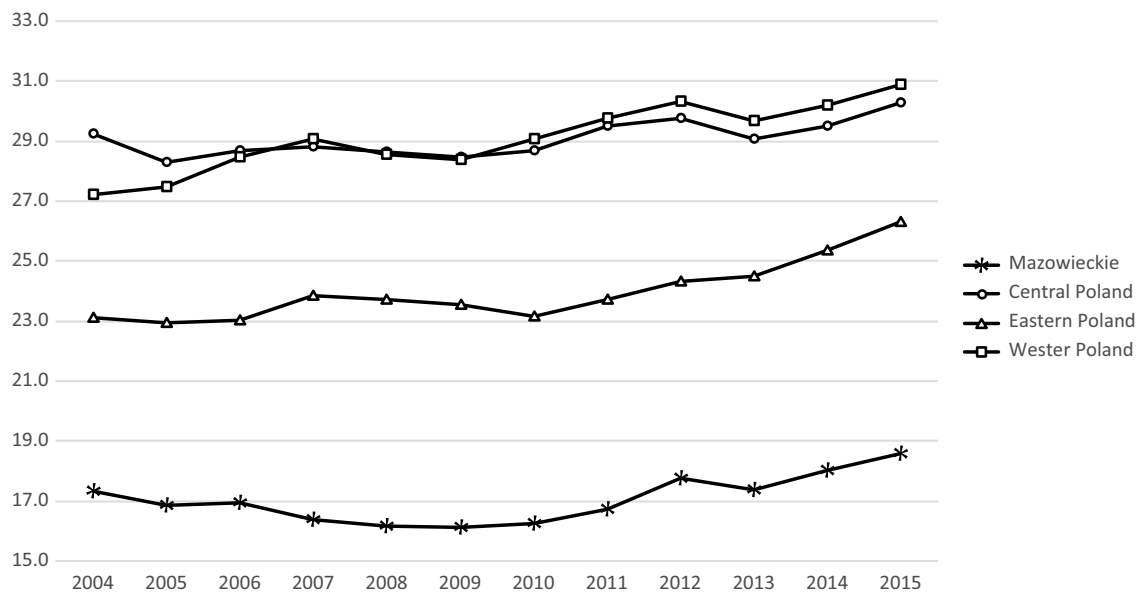

Figure 6.4 Share of gross value added in industry in voivodeship groups in 2004$2015(\%)$.

Source: Our own estimates based on: https://bdl.stat.gov.pl/BDL/start (access: 2019-12-30). 


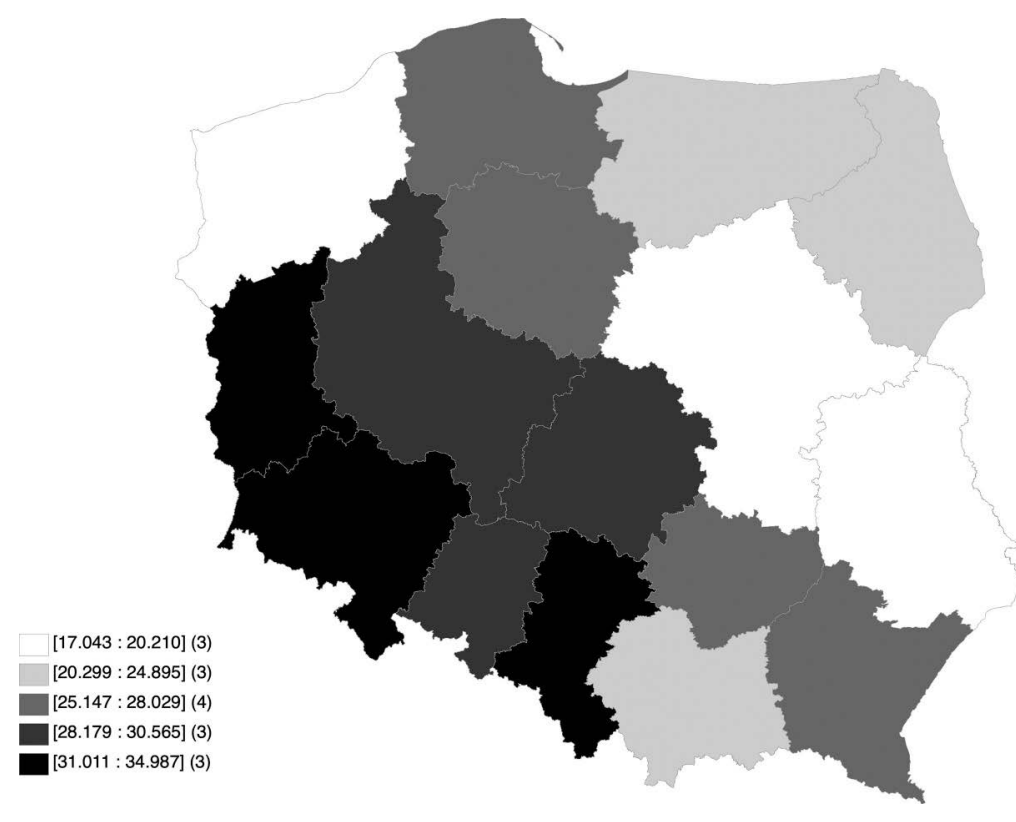

Map 6.4 Share of gross value added in industry in voivodeships in 2004-2015 (\%). Source: Our own estimates based on: https://bdl.stat.gov.pl/BDL/start (access: 2019-12-30).

industry was recorded in the Mazowieckie Voivodeship; in the entire analyzed period it did not exceed $19 \%$.

The average share of gross value added in industry in Poland in 20042015 was $25.7 \%$. The industrial sector had a significant share in the generated gross value added in the Śląskie (35.0\%), Dolnośląskie $(33.8 \%)$ and Lubuskie (31.0\%) voivodeships. The lowest shares of the gross value added of the considered sector were recorded in the following voivodeships: Lubelskie (20.2\%), Zachodniopomorskie (20.1\%) and Mazowieckie (17.0\%, more than twice less than in the Śląskie Voivodeship (see Map 6.4)).

\subsubsection{Value added in construction}

Figure 6.5 presents the gross value added in construction in groups of voivodeships in the years 2004-2015. The shape of the trajectories of these macroeconomic variables allows us to conclude that the value added in this sector did not fall after 2008, which means that the sector did not react to the global financial crisis. The effects of the crisis have probably been neutralized by significant infrastructure investments throughout Poland related to the organization of the Euro 2012 football tournament. A decrease in this variable can be perceived only in 2011-2013. In the last two analyzed years, the value added in construction increased once again in all groups of 


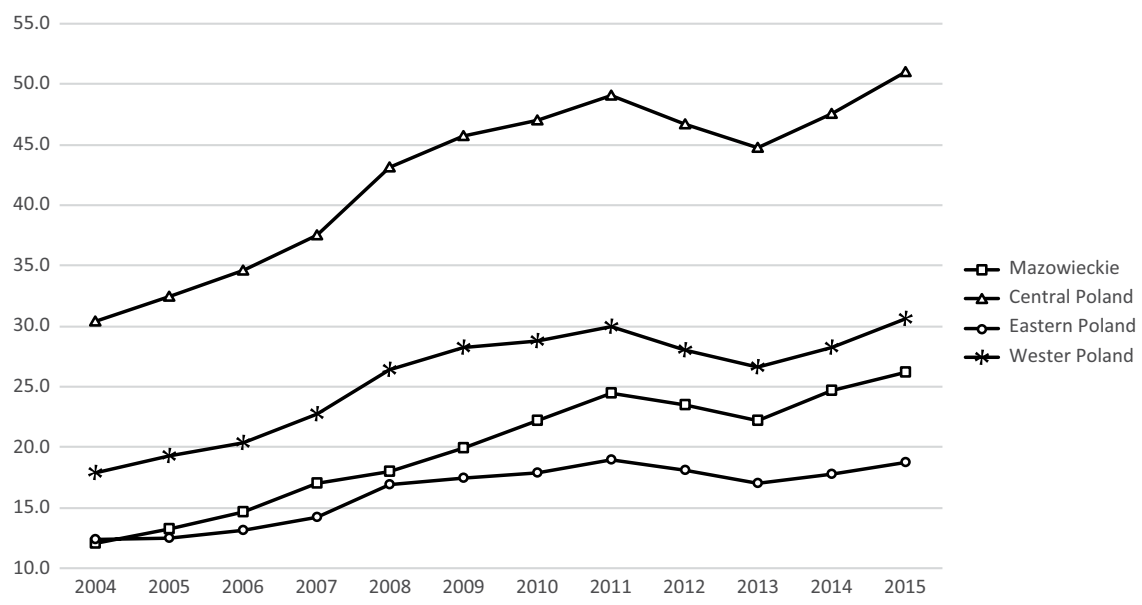

Figure 6.5 Gross value added in construction in voivodeship groups in 2004-2015 (PLN billion, according to 2015 prices).

Source: Our own estimates based on: https://bdl.stat.gov.pl/BDL/start (access: 2019-12-30).

voivodeships. Definitely the highest values of the variable under consideration were obtained in central Poland (PLN 28.7-48.7 billion), followed by western Poland (PLN 19.6-32.9 billion), Mazowieckie (PLN 12.1-26.2 billion) and the voivodeships of eastern Poland (PLN 12.4-18.7 billion). It is worth noting that the value added in the construction sector in the Mazowieckie Voivodeship in 2004 was similar to the value of this variable in the five voivodeships of eastern Poland. However, in the following years, there was a much more rapid growth of the construction sector located in the Mazowieckie Voivodeship, and in 2015 its potential was already about $40 \%$ greater than the potential of this sector in the voivodeships of eastern Poland.

Map 6.5 illustrates the spatial diversity of gross value added in voivodeships in 2004-2015. The following conclusions can be drawn from this map: The highest value added in construction was recorded in the Mazowieckie (PLN 19.9 billion), Śląskie (PLN 13.3 billion) and Wielkopolskie (PLN 10.1 billion) voivodeships. In turn, the Opolskie (PLN 2.3 billion), Podlaskie (PLN 2.3 billion) and Lubuskie (PLN 2.2 billion) voivodeships recorded the lowest values of this variable.

Figure 6.6 shows that the share of the gross value added in the construction sector in the voivodeships of eastern, central and western Poland was very similar. In the years $2004-2007$, it oscillated in the range of $7.2-7.7 \%$, and then in 2011 it attained a level of almost 9\%, while over the next two years it fell and in 2013 it was at a level of 7.5-8.0\%. The share of the construction sector in the Mazowieckie Voivodeship was slightly lower; however, in 
[2.151: 2.334] (3)

[2.895: 3.893] (3)

$[3.973: 5.759](4)$

[6.509: 9.846] (3)

$[10.090: 19.846](3)$

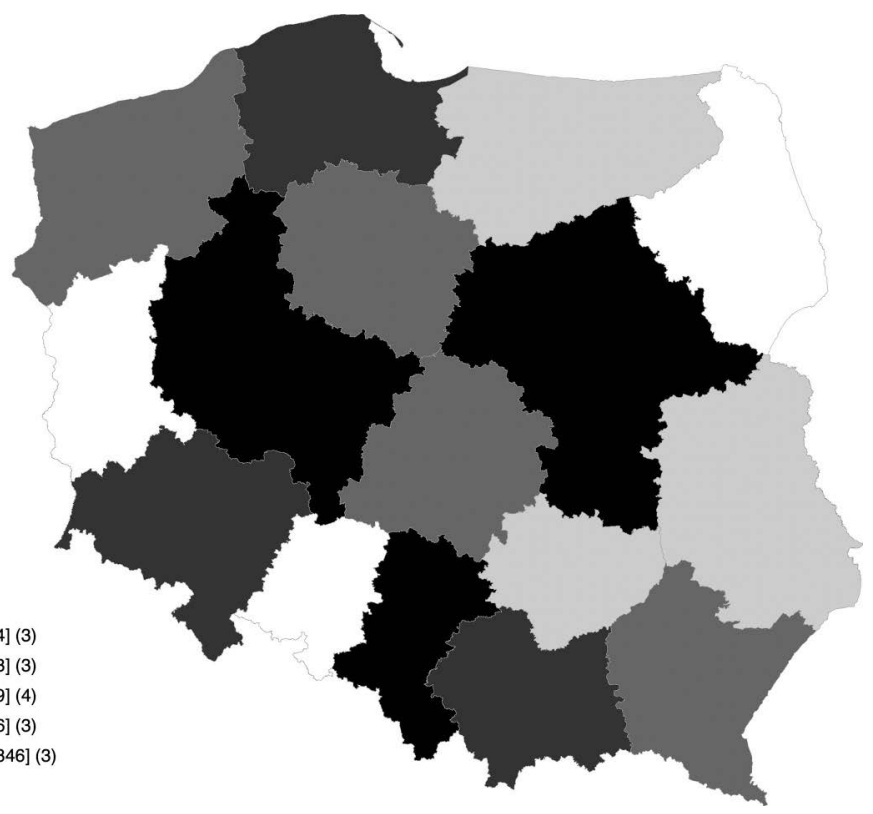

Map 6.5 Gross value added in construction in voivodeships in 2004-2015 (PLN billion, according to 2015 prices).

Source: Our own estimates based on: https://bdl.stat.gov.pl/BDL/start (access: 2019-12-30).

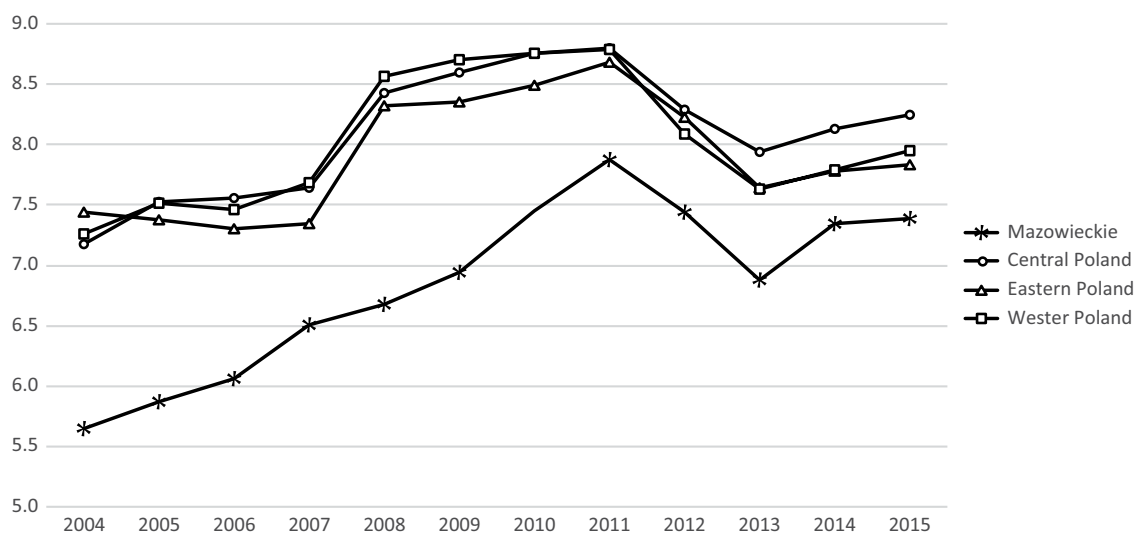

Figure 6.6 Share of gross value added in construction in groups of voivodeships in 2004-2015 (\%).

Source: Our own estimates based on: https://bdl.stat.gov.pl/BDL/start (access: 2019-12-30). 


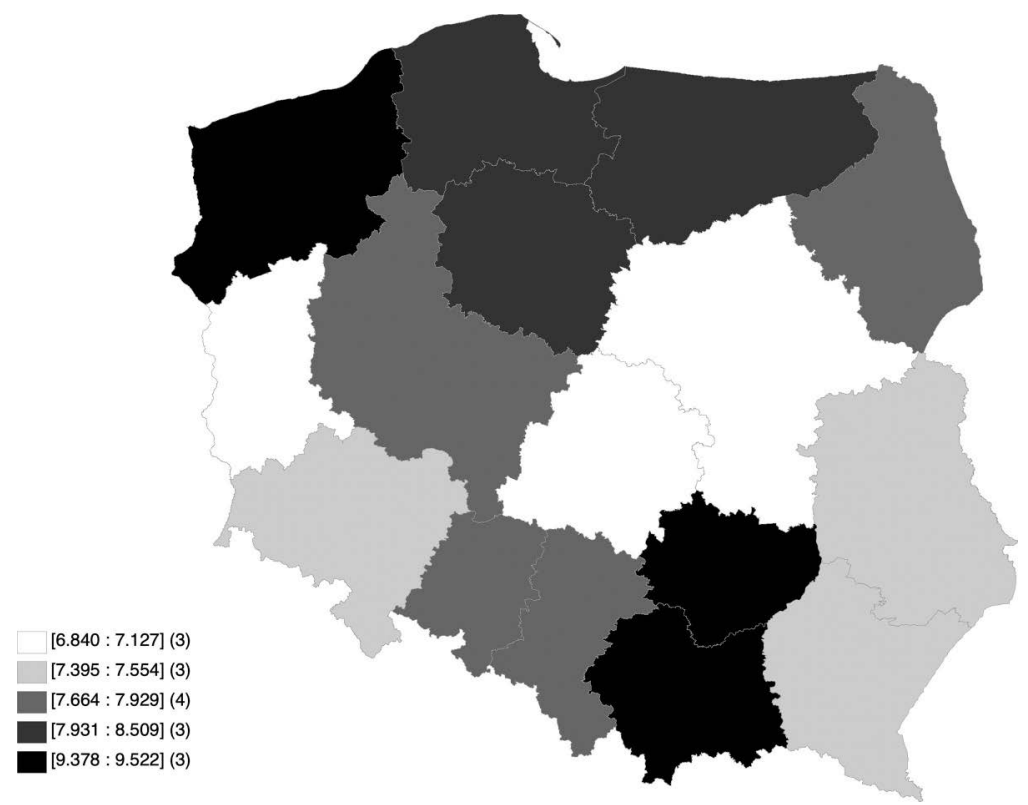

Map 6.6 Share of gross value added in construction in voivodeships on average in 2004-2015 (\%).

Source: Our own estimates based on: https://bdl.stat.gov.pl/BDL/start (access: 2019-12-30).

2004-2011 it increased from $5.6 \%$ to $7.9 \%$, then fell and in 2013 was at $6.9 \%$. In recent years, the importance of the construction sector is growing again in all voivodeship groups. In addition, when referring to 2004 to 2015, an increase in the variable under consideration by approx. $1.7 \%$ points in the Mazowieckie Voivodeship, 1.2\% points in central Poland voivodeships and below $1 \%$ point in the remaining groups of voivodeships can be observed.

The average gross value added in construction in Poland in the years 2004-2015 was 7.8\%. The highest gross value added in construction was recorded in the following voivodeships: Małopolskie (9.5\%), Zachodniopomorskie $(9.5 \%)$ and Świętokrzyskie $(9.4 \%)$. In turn, this sector (construction) had the least significance for the economies of the Lubuskie (7.1\%), Łódzkie (7.0\%) and Mazowieckie (6.8\%) voivodeships (Map 6.6).

\subsubsection{Added value in services}

The service sector is definitely the most important component of gross value added in the Polish economy. Figure 6.7 presents the added value in services in 2004-2015 in groups of voivodeships. In the analyzed period, in all groups of voivodeships, the value of this variable increased (by approx. $60 \%$ in the Mazowieckie Voivodeship, by $49 \%$ in western Poland, by $44 \%$ in central 


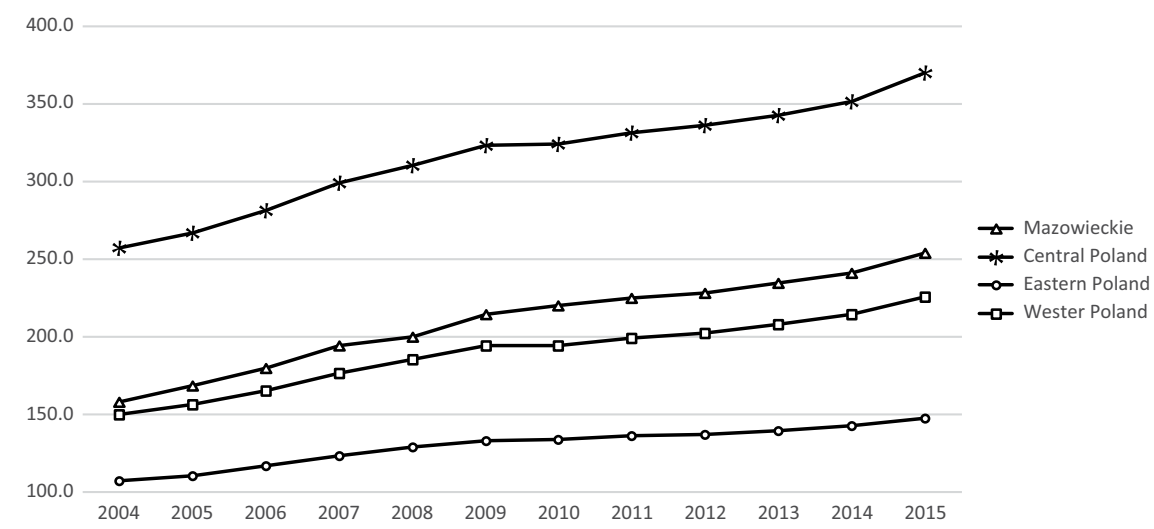

Figure 6.7 Gross value added in services in voivodeship groups in 2004-2015 (PLN billion, according to 2015 prices).

Source: Our own estimates based on: https://bdl.stat.gov.pl/BDL/start (access: 2019-12-30).

Poland and by $38 \%$ in eastern Poland). In addition, analyzing the trajectory of this variable, one can observe their response to the global financial crisis (a slowdown in the value of this variable) after 2008. This reaction results from the close links of this sector (primarily the financial and insurance industry) with the global economy. The highest added value in services in the whole analyzed period was recorded in the voivodeships of central Poland (PLN 242.4-349.9 billion). Voivodeships in eastern Poland had the lowest values of this trait (PLN 107.2-148.1 billion). It is also worth noting that the potential of the services sector in the Mazowieckie Voivodeship is similar to the potential of five voivodeships of western Poland and definitely higher than the potential of five voivodeships of eastern Poland.

By far the highest average value added in services was the Mazowieckie Voivodeship (PLN 209.7 billion). The following voivodeships were also distinguished by the high values of the analyzed variable: Śląskie (96.7 billion PLN) and Wielkopolskie (75.2 billion PLN). The lowest added values in services were recorded in the following voivodeships: Opolskie (PLN 2.3 billion), Podlaskie (PLN 2.3 billion) and Lubuskie (PLN 2.2 billion, see Map 6.7), which is mainly due to the low demographic and economic potential of these voivodeships.

Figure 6.8 presents the share of gross value added in groups of voivodeships in 2004-2015. In all groups this share remained at a stable, high level, although it should be emphasized that there was a slight decrease in this analyzed feature after 2008, which (as previously mentioned) was associated with the global financial crisis. The service sector is by far the most important for the Mazowieckie Voivodeship (in the analyzed period the shares of this sector were in the range of 71.6-74.5\%). In eastern Poland, the share of the services sector throughout the entire period changed between $61.9 \%$ and $65.2 \%$. 
[16.922: 19.469] (3) [20.529 : 32.463] (3) [34.283: 48.585] (4)

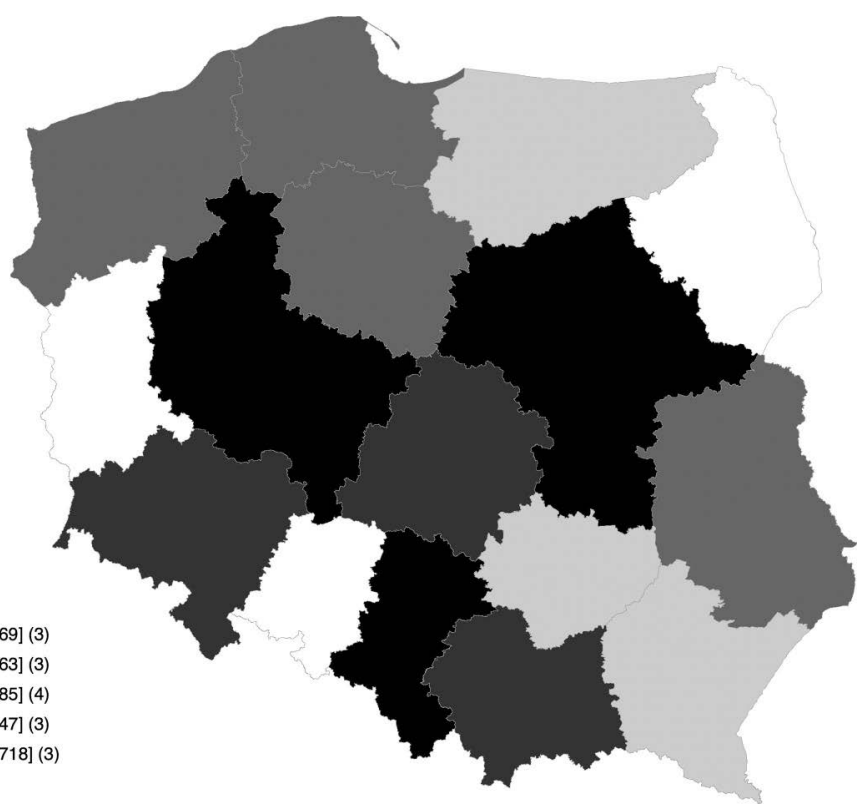

Map 6.7 Gross value added in services in voivodeships in 2004-2015 (PLN billion, according to 2015 prices).

Source: Our own estimates based on: https://bdl.stat.gov.pl/BDL/start (access: 2019-12-30).

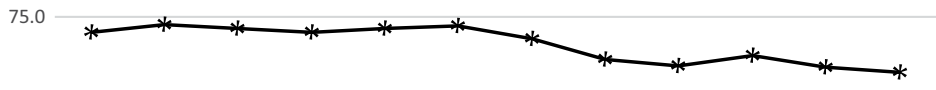

70.0

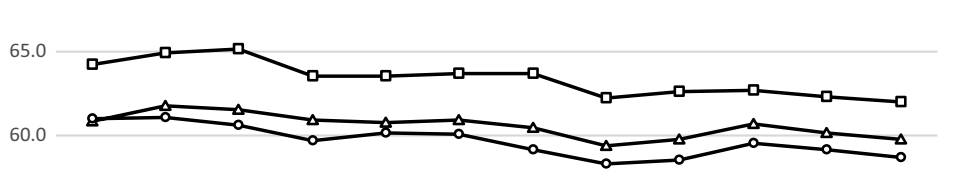

* Mazowieckie $\neg$ Central Poland $\longrightarrow$ - Eastern Poland - $\rightarrow$ Wester Poland

55.0

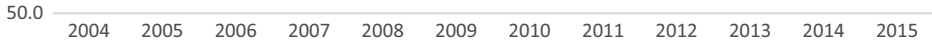

Figure 6.8 Share of gross value added in services in voivodeship groups in 2004$2015(\%)$

Source: Our own estimates based on: https://bdl.stat.gov.pl/BDL/start (access: 2019-12-30). 


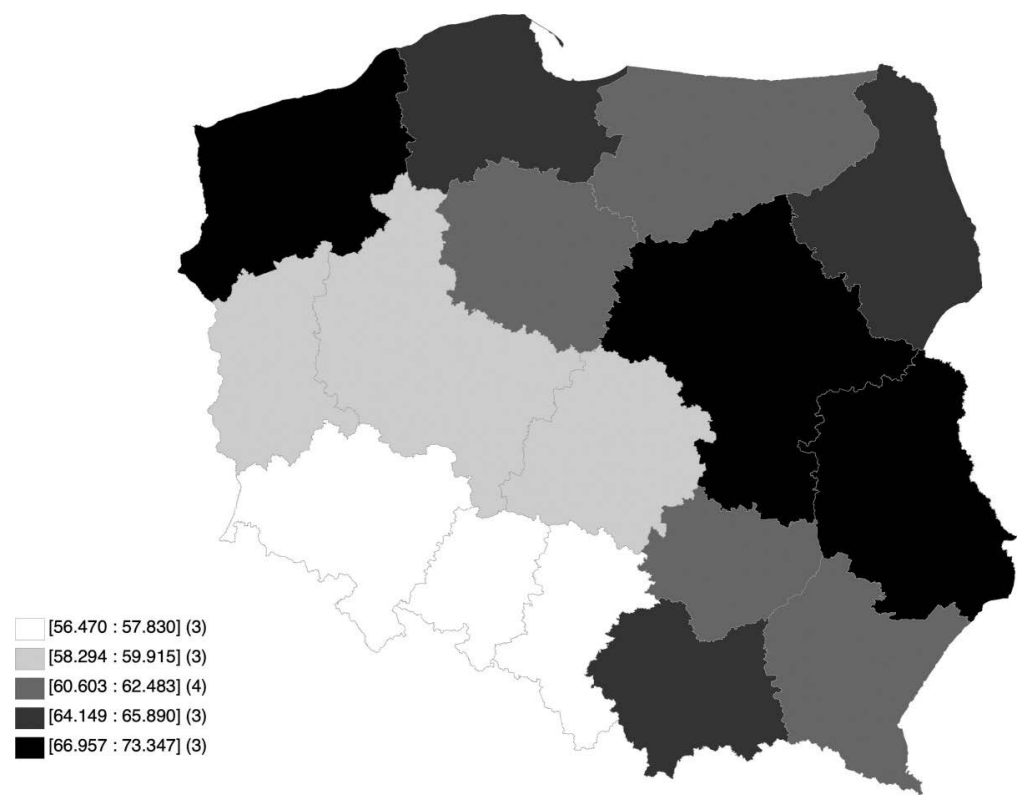

Map 6.8 Share of gross value added in services in voivodeships on average in 2004-2015 (\%).

Source: Our own estimates based on: https://bdl.stat.gov.pl/BDL/start (access: 2019-12-30).

In the other two groups, the level of this variable fluctuated around $60 \%$. Comparing 2015 with 2004, it turns out that in all groups of voivodeships the share of gross value added in services decreased (by $2.6 \%$ points in western Poland, by $2.4 \%$ points in the Mazowieckie Voivodeship, by $2.3 \%$ points and by $0.8 \%$ point in central Poland).

The average share of gross value added in the service sector in Poland in the years 2004-2015 was $63.5 \%$, and therefore this is the sector which definitely dominated in the economy. The service sector was of the greatest importance for the following voivodeships: Mazowieckie (73.4\%), Lubelskie (67.1\%) and Zachodniopomorskie (67.0\%). The lowest shares of the service sector in the gross value added were recorded in the following voivodeships: Opolskie (57.8\%), Dolnośląskie (57.1\%) and Śląskie (56.5\%, see Map 6.8).

\subsection{Sector structure of the product market in Ukraine}

\subsubsection{Added value in agriculture}

Figure 6.9 illustrates the trajectories of gross value added in agriculture in groups of Ukrainian oblasts in 2004-2016. This graph shows the following: First, at the beginning of the period under consideration, the highest value 


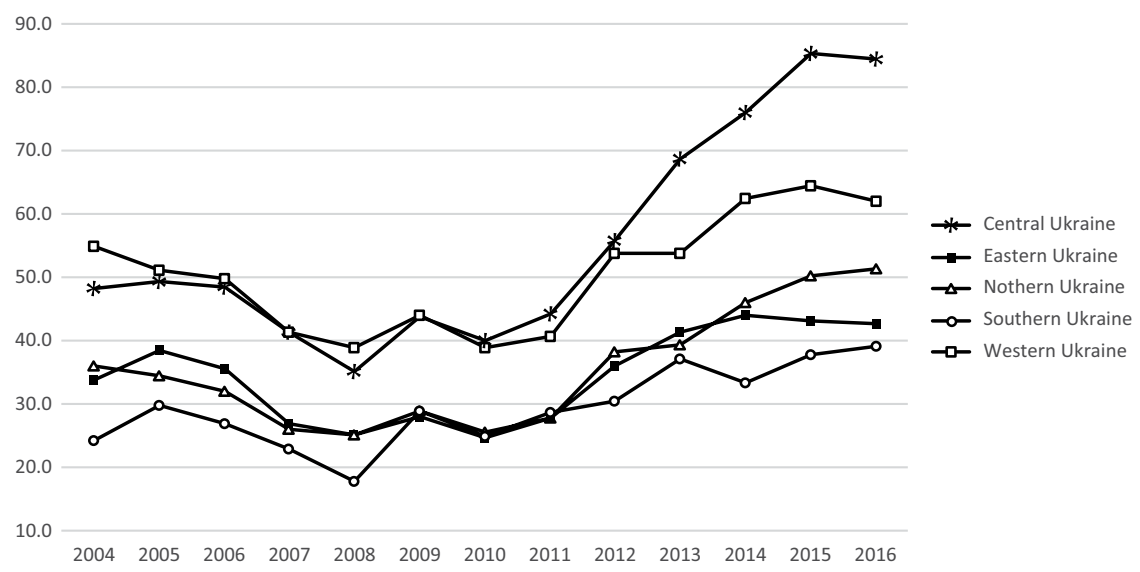

Figure 6.9 Gross value added in agriculture in oblasts groups in 2004-2016 (UAH billion, according to 2016 prices).

Source: Our own estimates based on: http://www.ukrstat.gov.ua/ (access: 2019-12-30).

of this macroeconomic variable was observed in the oblasts of western and central Ukraine (about 50 billion UAH). Second, in 2004-2008, the gross value added in agriculture fell (as a tendency) in all groups of regions. This can (paradoxically) be associated with a good economic situation in the non-agricultural sectors of the Ukrainian economy. During this period, the UAH strengthened against global currencies, ${ }^{3}$ which led to a relative decline in the price of imported food products, a decrease in demand for domestic products and a decrease in domestic agricultural production. Third, after 2010 , agricultural production basically increased in all oblasts groups. This can be explained by a reverse process to that which occurred in 2004-2009. During that period, the exchange rate rose to a level of $27.224 \mathrm{UAH}$ for the euro in December 2016. Fourth, in 2004-2016 the value added in agriculture grew the fastest in the regions of central (by $75.2 \%$ ) and southern Ukraine (by $61.5 \%$ ), while the slowest in the eastern (by $26.1 \%$ ) and western (by $13.2 \%$ ) regions of Ukraine.

However, Map 6.9 (illustrating the spatial differences in gross value added in agriculture on average in 2004-2016) shows that the largest (exceeding 10 billion $\mathrm{UAH}$ ) value of this macroeconomic variable was observed in the Kyiv region (13.1 billion UAH) in northern Ukraine, in the Vinnytsya (12.9 billion UAH) and in Dnipropetrovsk (12.3 billion UAH) oblasts in central Ukraine, in the Kharkiv Oblast (11.8 billion UAH) in eastern Ukraine and in the Poltava Oblast (11.5 billion UAH). The lowest absolute agricultural potential (except for Kyiv and Sevastopol) was found in the Rivne (5.9 billion UAH), Ivano-Frankivsk (5.6 billion UAH) and Volyn oblasts (5.4 billion UAH) in western Ukraine, in the Luhansk 


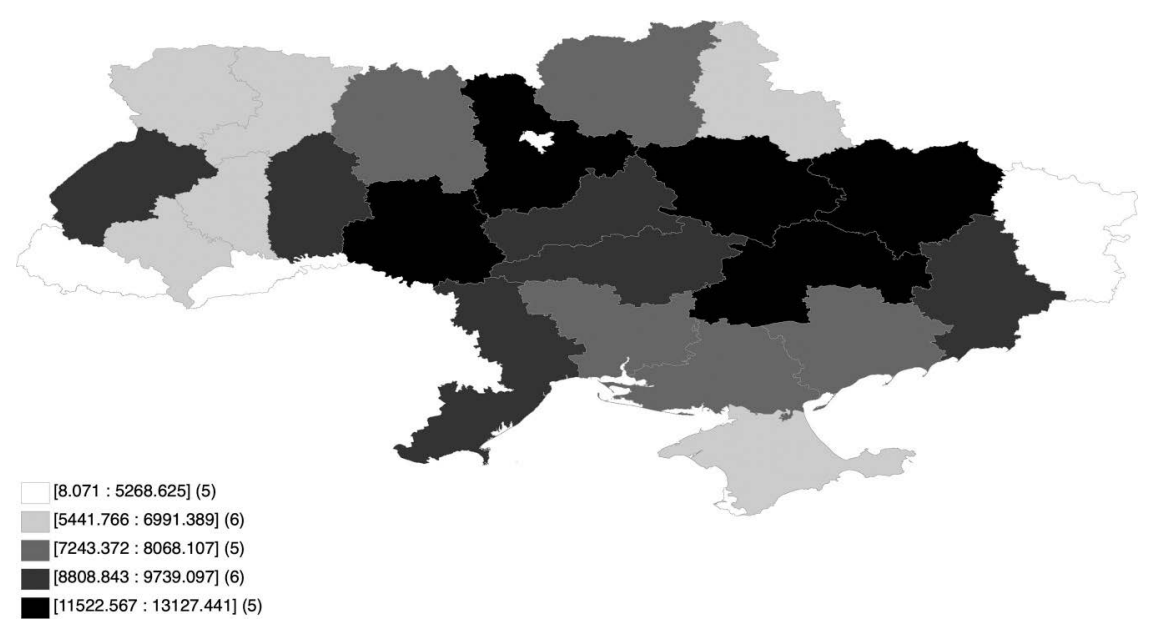

Map 6.9 Gross value added in agriculture in oblasts in 2004-2016 (UAH million, according to 2016 prices).

In the case of the ARC and Sevastopol in 2004-2013.

Source: Our own calculations based on data from the website http://www.ukrstat.gov.ua/ (access: 2019-12-30).

Oblast (5.3 billion UAH) in the east of Ukraine, as well as the Zakarpattia (4.9 billion UAH) and Chernivtsi oblasts (4.2 billion UAH) in the west. Thus, the agricultural potential of western Ukraine (much less urbanized than the other parts of the country) is lower than the potential of central or northern Ukraine.

Figure 6.10 shows the trajectories of the shares of gross value added in agriculture in total gross value added in groups of regions in 2004-2016. From this figure one can draw the following conclusions: First of all, in periods of good/bad economic situations in the Ukrainian economy, the share of gross value added (GVA) in agriculture in total (GVA) decreases/increases. This is due to the fact that, then, the value added in non-agricultural sectors of the economy usually increases (decreases) rapidly. In addition, in periods of good (bad) economic conditions there is a nominal appreciation (depreciation) of the UAH against foreign currencies. This, in turn, leads to a decrease (increase) in the relative prices of foreign food products compared to the prices of domestic products, and domestic consumers exchange domestic (foreign) products for foreign (domestic) products. Second, western, central and southern Ukrainian oblasts are characterized by a much higher share of agriculture in gross value added than the industrial oblasts of eastern Ukraine or the service-oriented oblasts of central Ukraine (mainly due to Kyiv together with the Kyiv Oblast). Third, the share of agriculture in gross value added in Ukrainian oblasts is much higher than in Polish voivodeships (see also Table 6.1). 
Table 6.1 Share of gross value added in groups of voivodeships (in 2003-2015) and groups of oblasts (in 2004-2016) in Poland and Ukraine (in \%)

\begin{tabular}{lcccc}
\hline Group of voivodeships and oblasts & Agriculture & Industry & Construction & Services \\
\hline Mazowieckie & 2.8 & 17.0 & 6.8 & 73.3 \\
Eastern Poland & 4.8 & 24.0 & 7.9 & 63.4 \\
Central Poland & 2.3 & 29.1 & 8.1 & 60.6 \\
Western Poland & 3.3 & 29.1 & 8.0 & 59.6 \\
Poland & $\mathbf{3 . 0}$ & $\mathbf{2 5 . 7}$ & $\mathbf{7 . 8}$ & $\mathbf{6 3 . 5}$ \\
Central Ukraine & 13.6 & 42.8 & 2.8 & 40.8 \\
Eastern Ukraine & 7.6 & 44.4 & 3.0 & 44.9 \\
North Ukraine & 6.5 & 16.0 & 4.7 & 72.8 \\
South Ukraine & 13.5 & 19.7 & 4.5 & 62.2 \\
Western Ukraine & 16.7 & 23.3 & 4.6 & 55.5 \\
Ukraine & $\mathbf{1 0 . 5}$ & $\mathbf{3 0 . 3}$ & $\mathbf{3 . 8}$ & $\mathbf{5 5 . 4}$ \\
\hline
\end{tabular}

Source: own calculations based on data from the website https://bdl.stat.gov.pl/BDL/start (access: 2019-12-30) and http://www.ukrstat.gov.ua/ (access: 2019-12-30).

Bold indicates whole country.

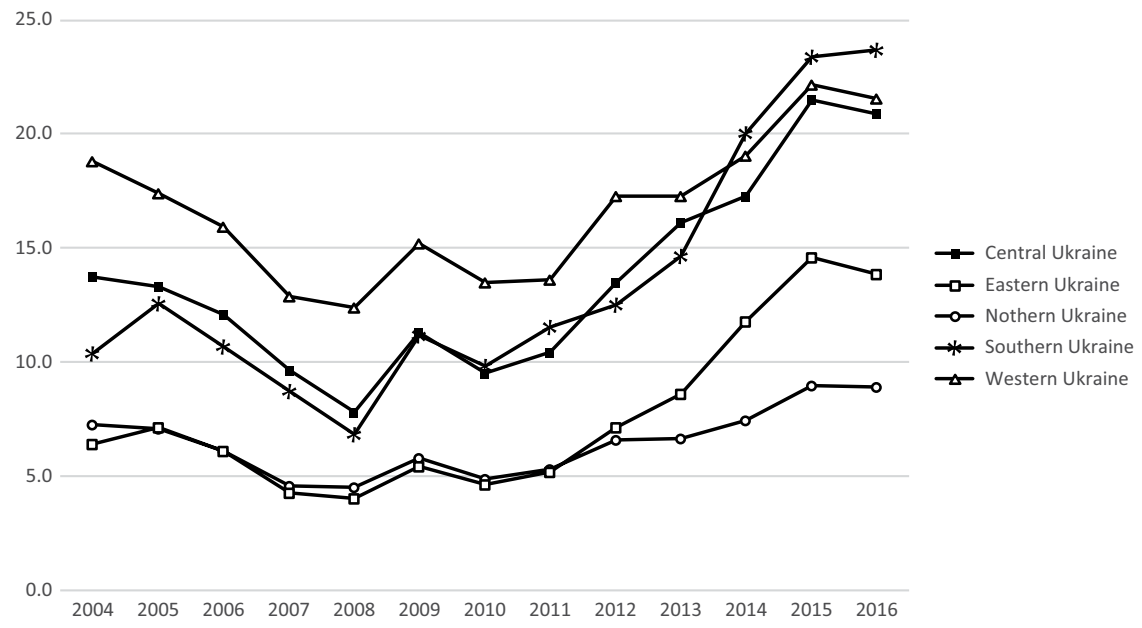

Figure 6.10 Share of gross value added in agriculture in oblasts in 2004-2016 (\%). Source: Our own calculations based on data from the website http://www.ukrstat.gov.ua/ (access: 2019-12-30).

Map 6.10 shows that the highest shares of gross value added in agriculture (in total gross value added) in 2004-2016 were observed in the Kyiv Oblast (26.2\%) in central Ukraine, Kherson Oblast (also 26.2\%) in southern Ukraine, Vinnytsya Oblast (25.4\%) in central Ukraine and the Ternopil Oblast $(24.0 \%)$ in western Ukraine. The lowest values of this indicator (excluding Kyiv and Sevastopol) were recorded in the Zaporizhzhya (9.8\%) and Luhansk $(9.5 \%)$ oblasts in eastern Ukraine, Odesa $(9.5 \%)$ in the south, and Dnipropetrovsk (6.3\%) in Central Ukraine and Donetsk (4.9\%) in eastern 


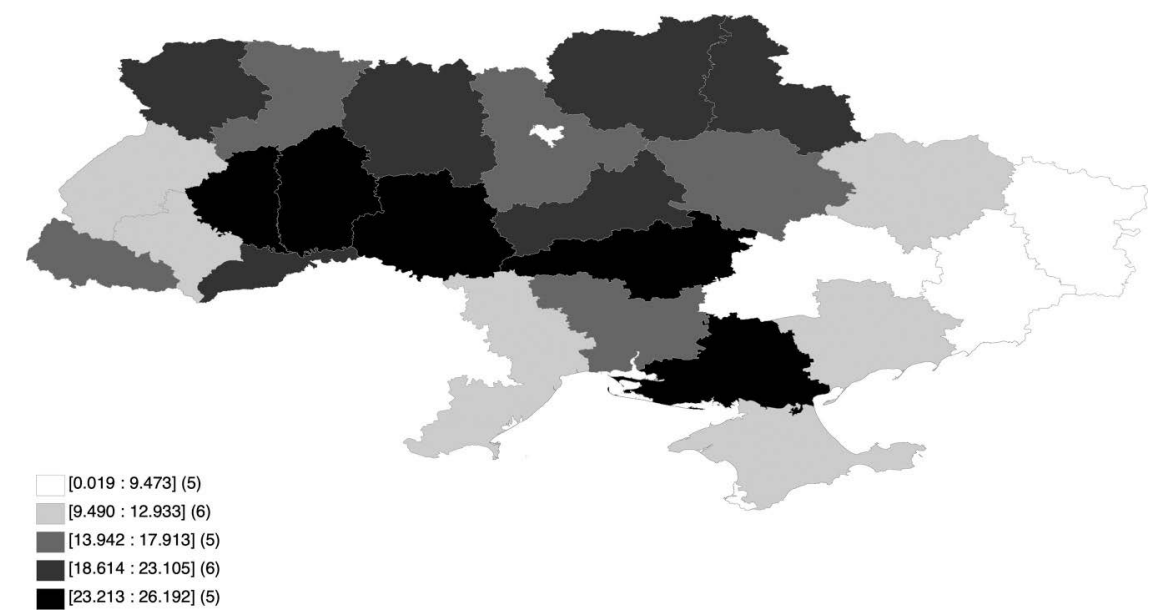

Map 6.10 Share of gross value added in agriculture in the oblasts on average in 2004-2016 (\%).

In the case of the ARC and Sevastopol in 2004-2013.

Source: Our own calculations based on data from the website http://www.ukrstat.gov.ua/ (access: 2019-12-30).

Ukraine. Therefore, the more urbanized oblasts of the Left-bank Ukraine (except for the Kirovohrad and Kherson oblasts) are generally characterized by a lower share of gross value added generated in agriculture than the oblasts of Right-bank Ukraine.

\subsubsection{Added value in industry}

Gross value-added trajectories in oblast groups in 2004-2016 are presented in Figure 6.11. The following conclusions can be drawn from this graph: First, at the beginning of the period under consideration, the highest gross value added in industry was found in (the most highly urbanized and most industrialized) oblasts of eastern Ukraine. The value of this macroeconomic variable increased in eastern Ukraine from 252.2 billion UAH in 2004 to 314.8 billion UAH in 2007. Second, the high value of this feature was characteristic of the central Ukrainian oblasts, where the gross value added in industry increased from 141.4 billion UAH to 196.0 billion UAH. Third, the lowest gross value added in industry was recorded in the southern oblasts of Ukraine, where the value of this characteristic increased from 51.2 billion UAH in 2004 to 59.8 billion UAH in 2008. Fourth, the global financial crisis combined with the Ukrainian-Russian gas crisis led to a decrease in the value of this macroeconomic variable in 2008 or 2009.

The highest gross value added in 2007-2009 fell in western Ukraine (by $33.4 \%$ ), and the slowest in southern Ukrainian oblasts (by 13.2\%) (Amosha et al. 2017). Fifth, in the years 2010-2013, the oblasts of central, northern 


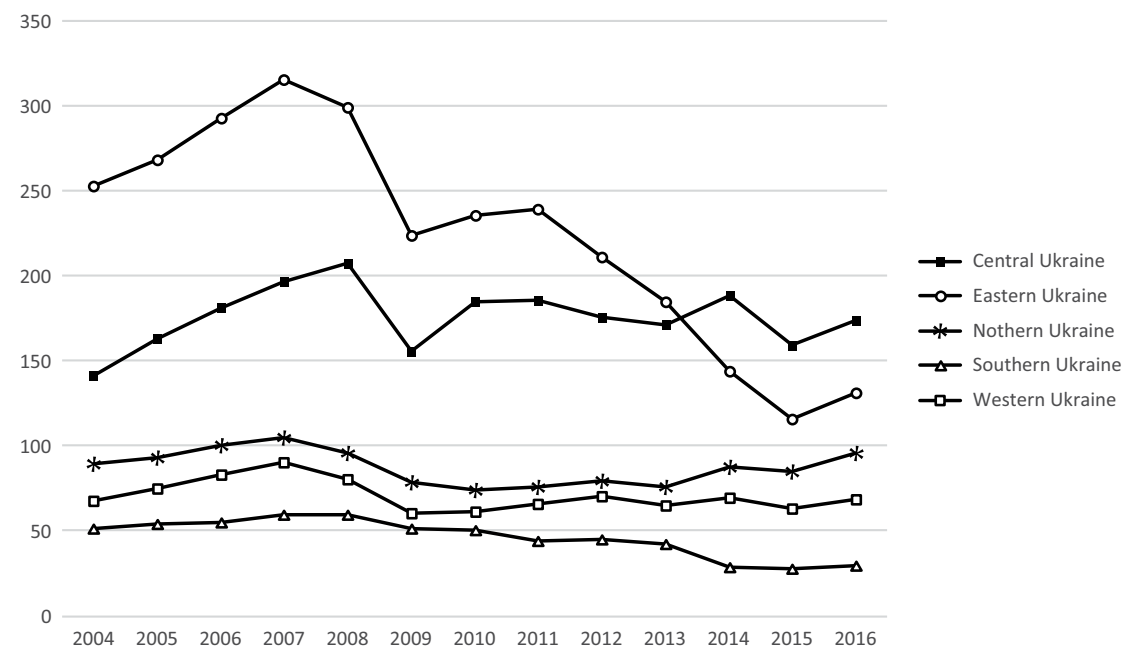

Figure 6.11 Gross value added in industry in oblasts groups in 2004-2016 (UAH billion, according to 2016 prices).

Source: Our own calculations based on data from the website http://www.ukrstat.gov.ua/ (access: 2019-12-30).

and western Ukraine were characterized (as a tendency) by a growing gross value added in industry. Sixth, in the years 2013-2015, in all groups of oblasts (with the exception of central Ukraine) the value of the analyzed variable decreased. Seventh, in the east of Ukraine, the gross value added in industry has been falling since 2012 (in 2016 the value of this macroeconomic variable was as much as $45.3 \%$ lower than in 2011). This resulted from both the Russian-Ukrainian conflict in the Donbas and from falling investments in this part of the country (in 2017, investments in eastern Ukraine constituted only $44.6 \%$ of the value of this macroeconomic variable in 2011).

Map 6.11 shows the spatial differentiation of gross value added in industry in the oblasts of Ukraine on average in 2004-2016. This map shows that the group of oblasts with the highest value of this macroeconomic variable was composed of cities with a special status, that is, Kyiv (119.1 billion UAH) and of the following oblasts: Donetsk (43.6 billion UAH), and Dnipropetrovsk (41.6 billion UAH), Kyiv (33.9 billion UAH) and Kharkiv (26.2 billion UAH). The lowest gross value added in this sector of the economy was recorded in another city with a special status, that is, Sevastopol (3.8 billion UAH), and in the Chernivtsi (5.2 billion UAH), Ternopil (5.4 billion UAH), Kherson (5.8 billion UAH) and Chernihiv oblasts ( 6.0 billion UAH). From Map 6.11 one can also draw a more general conclusion that the better urbanized regions of the Left-bank of Ukraine were characterized by a much higher absolute potential of the industrial sector than the regions of the Right-bank of Ukraine. 


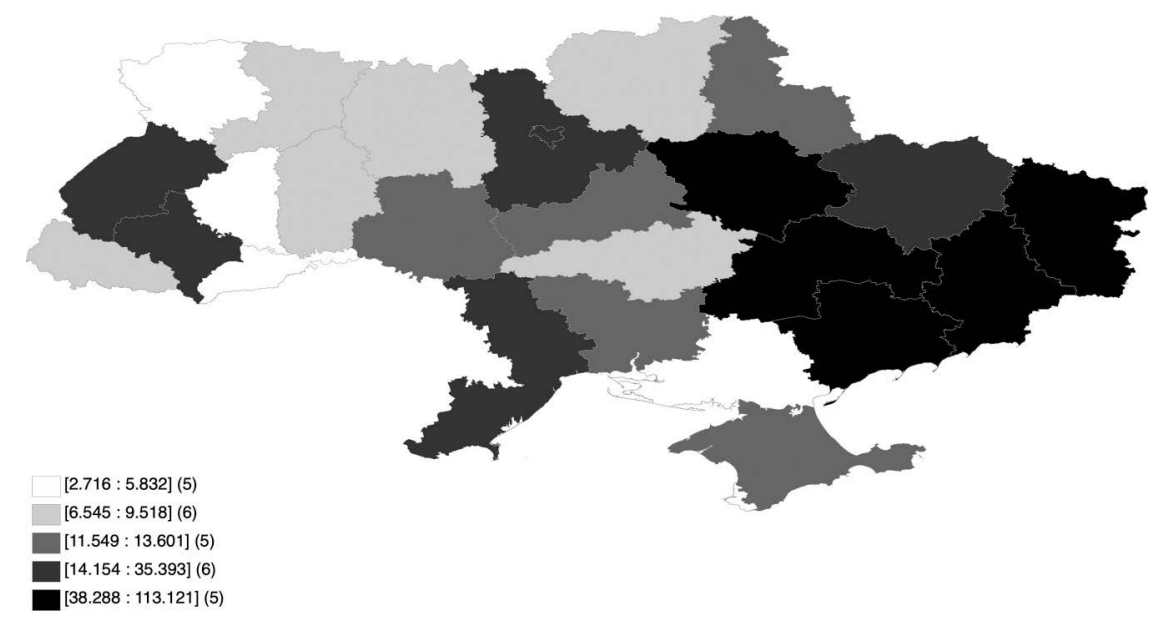

Map 6.11 Gross value added in industry in oblasts in 2004-2016 (UAH billion, according to 2016 prices).

In the case of the ARC and Sevastopol in 2004-2013.

Source: Our own calculations based on data from the website http://www.ukrstat.gov.ua/ (access: 2019-12-30).

Figure 6.12 illustrates the share of gross value added in industry in total gross value added in groups of oblasts in the research period. This graph shows the following: Until 2009, the oblasts of eastern Ukraine were characterized by the highest (generally exceeding $45 \%$ ) share of gross value added in industry. At that time, the region of central Ukraine was characterized by a high value, exceeding $40 \%$. Starting from 2010 , the share of gross value added in these two groups of oblasts was at a similar level. This was mainly due to the fact that since 2009, industrial production in eastern Ukraine has been systematically falling (see Figure 6.11). The lowest percentage of gross value added generated in industry was recorded in northern Ukraine. This is due to the fact that in this part of Ukraine, gross production is produced in Kyiv and the Kyiv Oblast. There, and in particular in Kyiv, the service sector is the dominant sector of the economy. It is also worth noting that (except for the oblasts of northern Ukraine after 2013) the share of gross value added in industry in this research decreased.

The highest share of gross value added in industry (in total gross value added) in 2004-2016 was observed in the following oblasts: Dnipropetrovsk (51.8\%), Donetsk (50.1\%), Luhansk(50.0\%), Poltava (49.1\%) and Zaporizhzhya $(47.3 \%)$. The lowest value of this feature was recorded in the city with a special status, that is, Kyiv $(10.0 \%)$, and in the following oblasts: Chernivtsi (13.7\%), Odesa (16.6\%), Ternopil (17.0\%) and Volyn (18.5\%). Thus, the more highly urbanized oblasts located in Left-bank Ukraine were characterized by a higher share of gross value added in construction than those oblasts of the Right-bank Ukraine (see Map 6.12). 


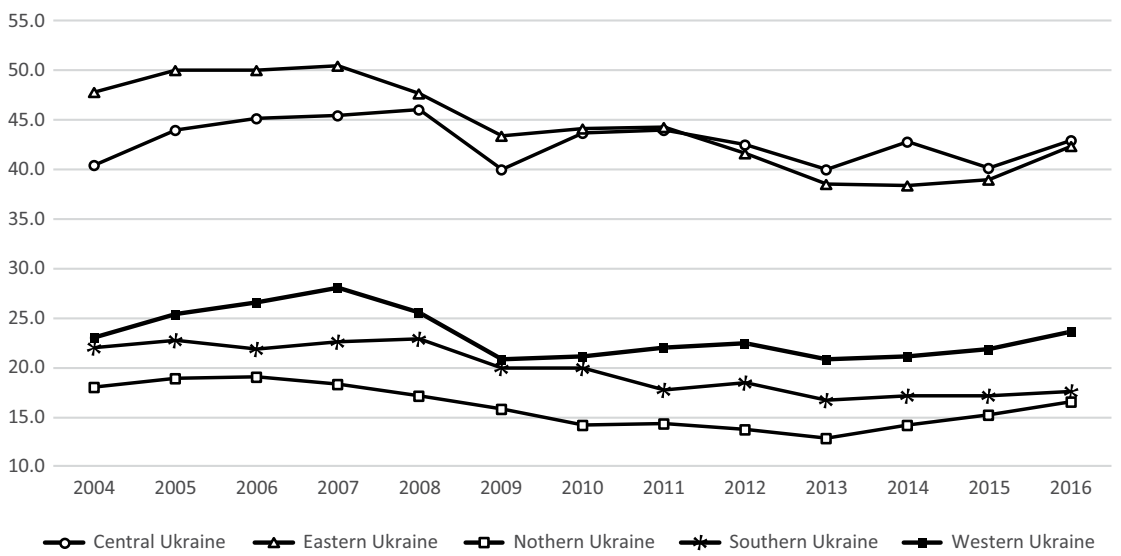

Figure 6.12 Share of gross value added in industry in oblasts in 2004-2016 (\%). Source: Our own calculations based on data from the website http://www.ukrstat.gov.ua/ (access: 2019-12-30).

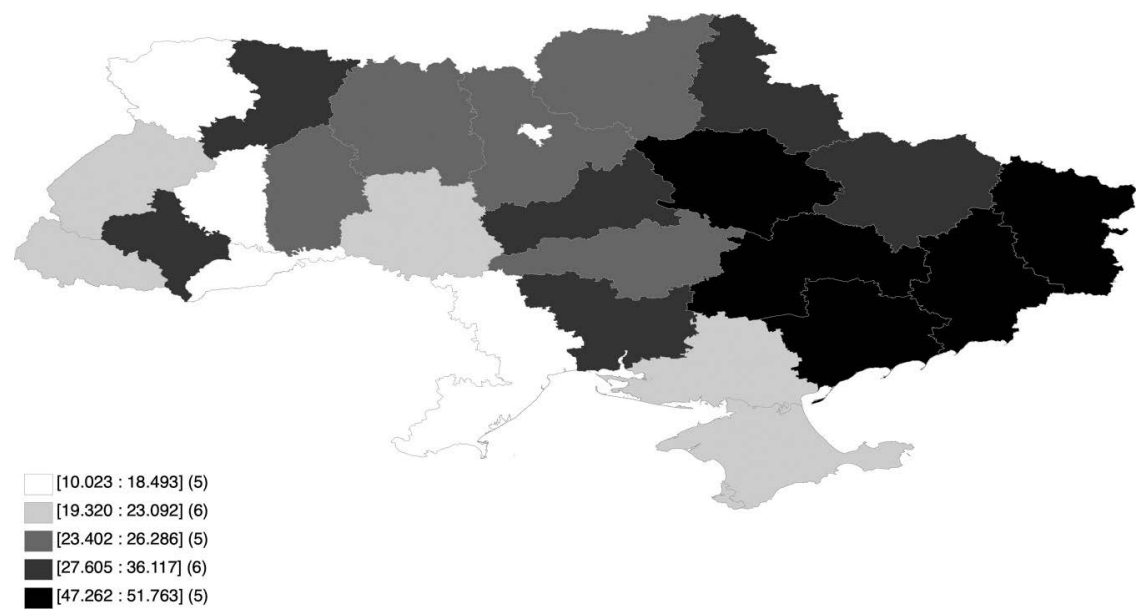

Map 6.12 Share of gross value added in industry in oblasts in 2004-2016 (\%). In the case of the ARC and Sevastopol in 2004-2013.

Source: Our own calculations based on data from the website http://www.ukrstat.gov.ua/ (access: 2019-12-30).

\subsubsection{Added value in construction}

Figure 6.13 illustrates gross value-added trajectories in construction in oblast groups. From this figure one can draw the following conclusions: First, the construction sector is characterized by the highest procyclicality among the four sectors of the Ukrainian economy. Second, the oblasts of 


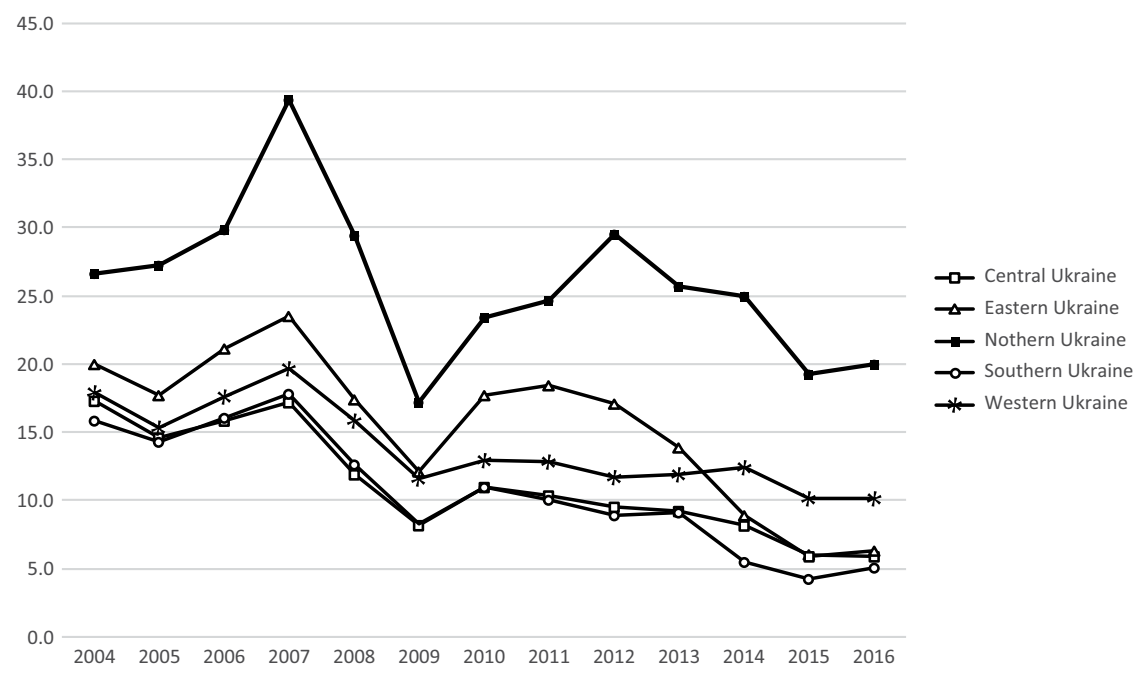

Figure 6.13 Gross value added in construction in oblasts groups in 2004-2016 (billion UAH, according to 2016 prices).

Source: Our own calculations based on data from the website http://www.ukrstat.gov.ua/ (access: 2019-12-30).

northern Ukraine had by far the highest value of this feature (mainly due to Kyiv and partially due to the Kyiv Oblast).

Third, the lowest value of this feature was recorded in the group of oblasts of south and central Ukraine and (after the Euro-Maidan) in the east of Ukraine.

In the whole research period, the capital of Kyiv definitely had the highest value of this variable (18.6 billion UAH). Next in line were the following oblasts: Donetsk (6.9 billion UAH), Odesa (5.0 billion UAH), Kharkiv (4.9 billion UAH) and Dnipropetrovsk (4.6 billion UAH). These are the oblasts in which the largest Ukrainian cities are located (except Lviv). However, the lowest value of this feature was recorded in the Kherson Oblast ( 0.7 billion UAH), a city with a special status, that is, Sevastopol ( 0.7 billion UAH), Ternopil ( 0.9 billion UAH), Sumy ( 0.9 billion UAH) and the Chernihiv Oblast (1.0 billion UAH). Moreover, Left-bank Ukraine was characterized by a higher absolute potential of the construction sector than Right-bank Ukraine (see Map 6.13).

Analyzing the share of the gross value added in the construction sector in the gross value added of the entire Ukrainian economy, it turns out that the eastern and central Ukrainian oblasts were characterized by a much lower value of this characteristic than the other oblast groups. Moreover, the share of this sector in total gross value added in all groups of oblasts decreased significantly during the Russian-Ukrainian gas conflict. In addition, it should be noted that after the Polish-Ukrainian Euro 2012 football 


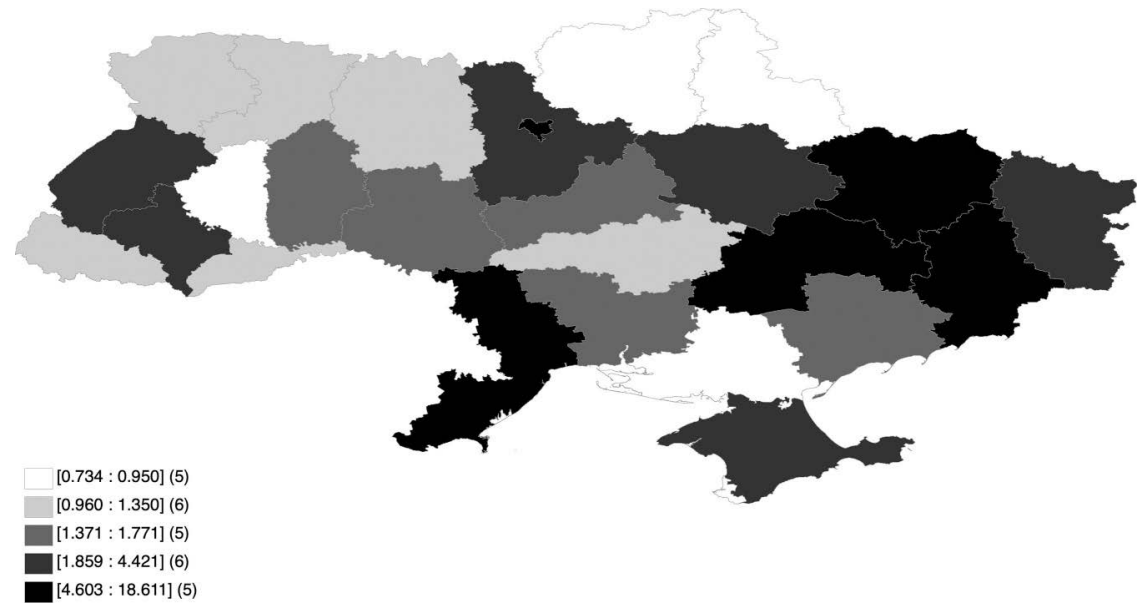

Map 6.13 Gross value added in agriculture in oblasts in 2004-2016 (UAH billion, according to 2016 prices).

In the case of the ARC and Sevastopol in 2004-2013.

Source: Our own calculations based on data from the website http://www.ukrstat.gov.ua/ (access: 2019-12-30).

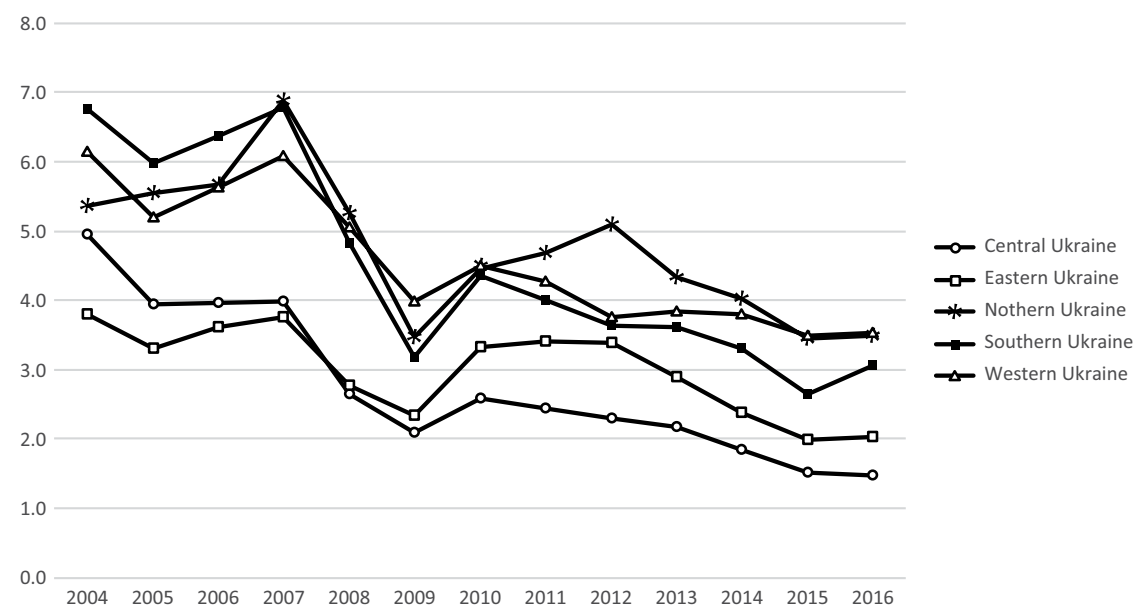

Figure 6.14 Share of gross value added in construction in oblasts groups in 2004$2016(\%)$.

Source: Our own calculations based on data from the website http://www.ukrstat.gov.ua/ (access: 2019-12-30).

tournament, in all oblast groups, the value of this analyzed macroeconomic variable manifested a tendency to decrease (see Figure 6.14).

On average, in the entire period under consideration, the highest share of construction in the gross value added generated was recorded in the 


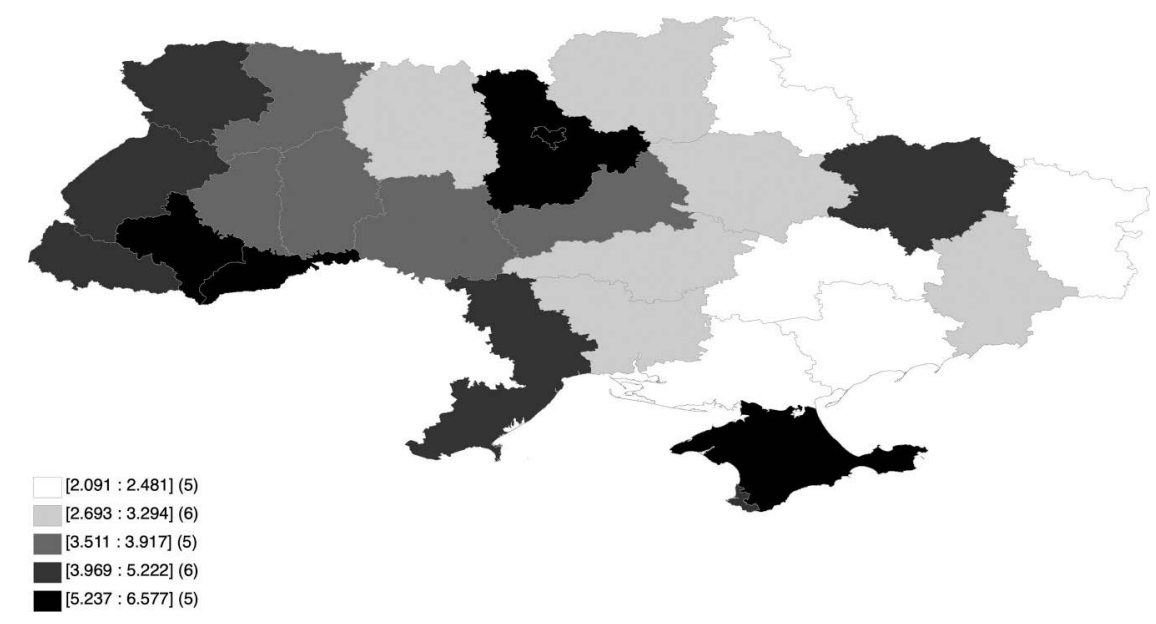

Map 6.14 Share of gross value added in industry in oblasts in 2004-2016 (\%). In the case of the ARC and Sevastopol in 2004-2013.

Source: Our own calculations based on data from the website http://www.ukrstat.gov.ua/ (access: 2019-12-30).

Ivano-Frankivsk Oblast (6.6\%), the Autonomous Republic of Crimea (5.9\%), the Chernivtsi Oblast (5.9\%) and Kyiv Oblast (5.4\%) and in the City of Kyiv. The lowest value of this feature was observed in the Zaporizhzhya (2.1\%), Dnipropetrovsk (2.3\%), Luhansk (2.4\%), Sumy (2.5\%) and Kherson (2.5\%) oblasts. Moreover, the spatial differentiation of this feature (in contrast to the analogous index for industry) does not show a clear division of Ukraine into its right and left bank (see Map 6.14).

\subsubsection{Added value in services}

Figure 6.15 illustrates the gross value-added trajectories in the service sector. The following conclusions can be drawn from this graph. First of all, the oblasts of northern Ukraine had by far the highest value of this feature (roughly in the range of $350-450$ billion UAH). This is due to the fact that Kyiv and the Kyiv Oblast are located in the north of Ukraine (on average, in 2004-2016, the value added of the services sector in Kyiv accounted for approx. $27 \%$ of the value of this variable throughout Ukraine, while in Kyiv together with the Kyiv Oblast over $31 \%$ ). Second, up to the time of the Euro-Maidan, the oblasts of eastern Ukraine were characterized by a high potential of the construction sector (the gross value added of services was at a level of 200-250 billion UAH). However, the conflict in Donbas led to a decrease in the value of this feature in eastern Ukrainian oblasts in 2013-2016 by approximately 100 billion UAH (and therefore by about $40 \%$ ). Third, as a result of the annexation of Crimea, the gross value added in southern Ukrainian oblasts fell after 2013 by approximately 50 billion UAH, and thus 


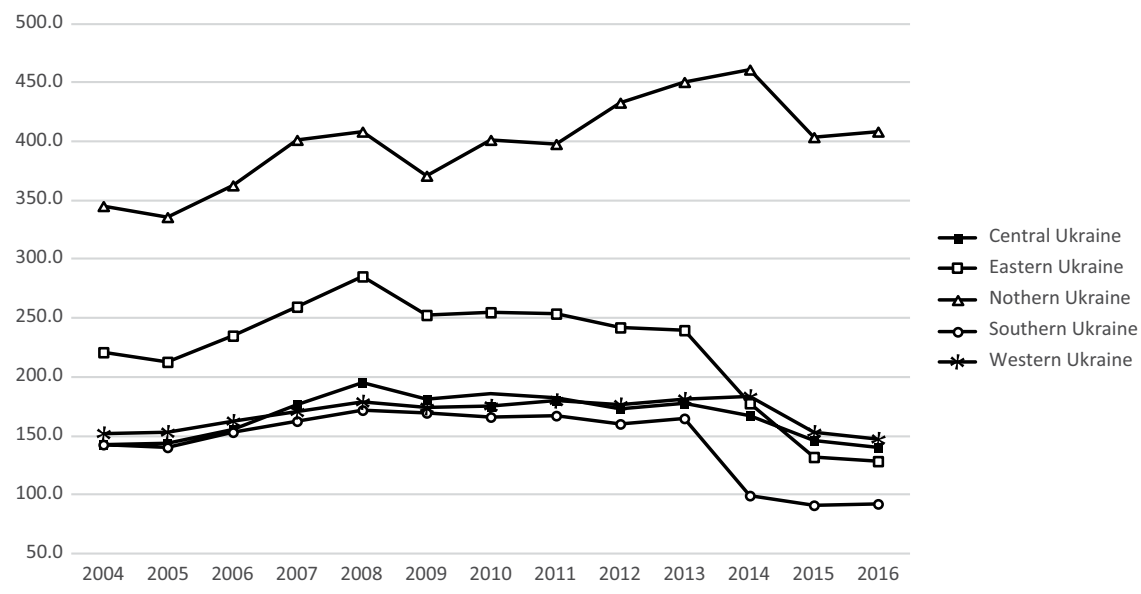

Figure 6.15 Gross value added in services in oblast groups in 2004-2016 (billion UAH, according to 2016 prices).

Source: Our own calculations based on data from the website http://www.ukrstat.gov.ua/ (access: 2019-12-30).

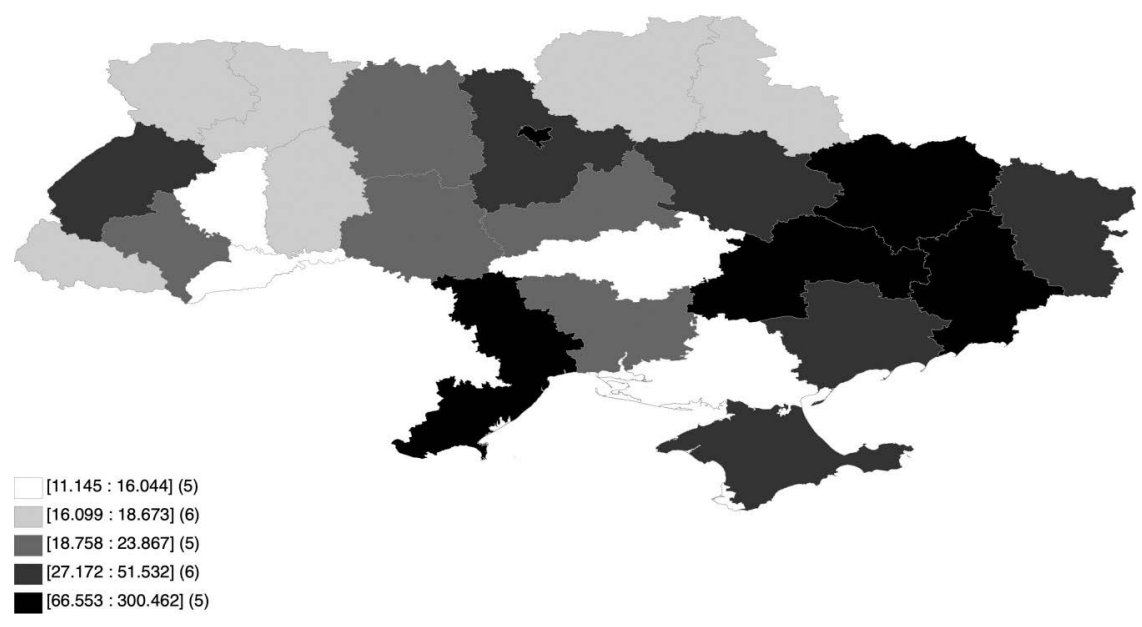

Map 6.15 Value added in services in oblasts on average in 2004-2016 (billion UAH, according to 2016 prices).

In the case of the ARC and Sevastopol in 2004-2013.

Source: Our own calculations based on data from the website http://www.ukrstat.gov.ua/ (access: 2019-12-30).

roughly $1 / 3$ of its value before the Euro-Maidan. Fourth, the service sector in Ukraine is characterized by a prominent procyclicality.

Map 6.15 illustrates the spatial differentiation of gross value added in the oblasts of Ukraine in 2004-2016. This map and data on that feature show 


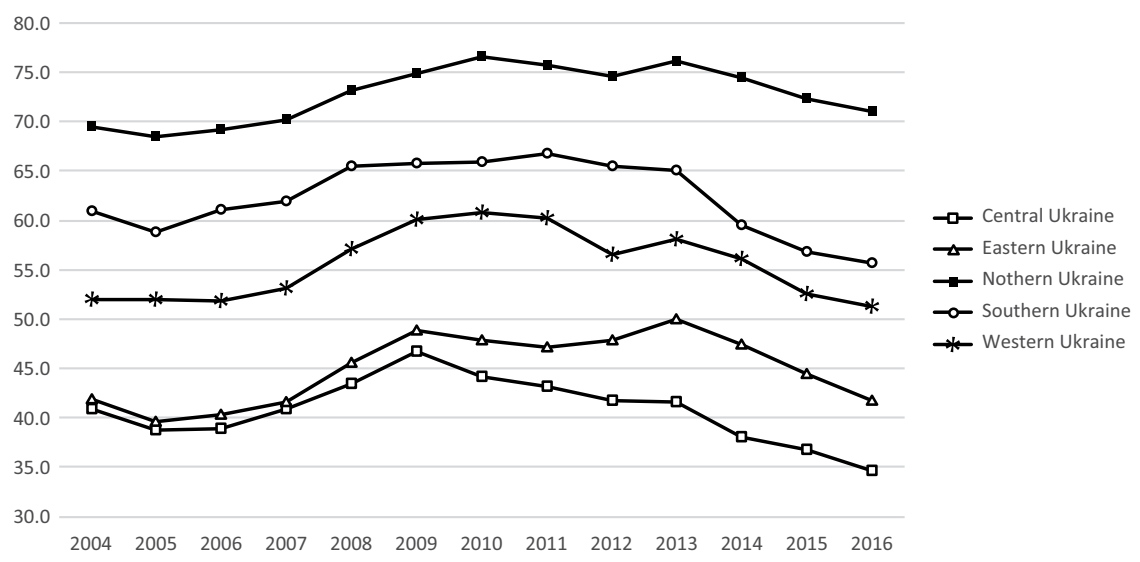

Figure 6.16 Share of gross value added in construction in oblast groups in 2004$2016(\%)$.

Source: Our own calculations based on data from the website http://www.ukrstat.gov.ua/ (access: 2019-12-30).

that the capital City of Kyiv had by far the highest gross value added in services (UAH 300.5 billion), among oblasts. A high value of this variable was also observed in the following oblasts: Donetsk (92.5 billion UAH), Dnipropetrovsk (79.7 billion UAH), Kharkiv (69.2 billion UAH), Odesa (66.6 billion UAH) and Lviv (51.5 billion UAH). So, this group is composed of oblasts in which the largest Ukrainian cities are located. However, the group of oblasts with the lowest service potential was composed of a city with a special status of Sevastopol (11.1 billion UAH) and the following oblasts: Chernivtsi (11.6 billion UAH), Ternopil (14.3 billion UAH), Kherson (15.4 billion UAH) and Kirovohrad (16.0 billion UAH). Thus, the level of the potential of the service sector (as well as of the industrial sector) on the left bank of Ukraine is much higher than in the oblasts located on the right bank of the Dnieper.

Figure 6.16 shows the trajectories of the shares of gross value added in agriculture in total gross value added in groups of oblasts in 2004-2016. From this figure one can draw the following conclusions: First, the oblasts of northern Ukraine had by far the highest value of this macroeconomic variable $(68.5-76.5 \%)$. Second, the lowest share of gross value added in services was recorded in central (34.6-46.7\%) and eastern Ukraine (39.6-50.0\%). Third, this share is much less procyclical than in the case of the corresponding shares of the industrial and construction sectors.

Map 6.16 illustrates the share of gross value added in total gross value added in 2004-2016. This map shows that Kyiv (84.7\%) possessed by far the highest value of this trait, followed by Sevastopol $(75.6 \%)$, the Odesa Oblast (68.6\%), the Autonomous Republic of Crimea (64.3\%) and the Lviv Oblast 


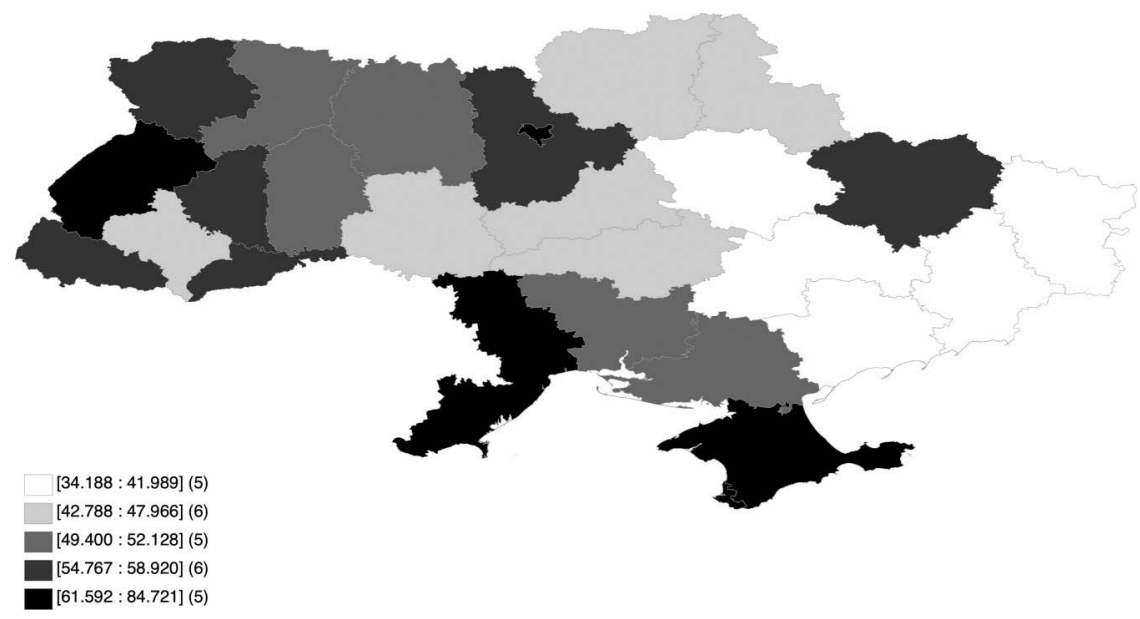

Map 6.16 Share of gross value added in industry in oblasts in 2004-2016 (\%). In the case of the ARC and Sevastopol in 2004-2013.

Source: Our own calculations based on data from the website http://www.ukrstat.gov.ua/ (access: 2019-12-30).

$(61.6 \%)$. The lowest share of gross value added in total gross value added was recorded in the following regions: Poltava (34.2\%), Luhansk (38.2\%), Dnipropetrovsk (39.6\%), Zaporizhzhya (40.8\%) and Donetsk (42, $0 \%)$.

\subsection{Summary}

Table 6.1 summarizes the data on sectoral product market structures in groups of voivodeships and regions during the research period of this chapter. The following conclusions can be drawn from this map:

i The share of the service sector in the gross value added generated in Poland was higher than in Ukraine, while the share of agriculture was significantly lower. This means that the sectoral structure of the product market in Poland is more similar than in Ukraine to the more economically developed countries of western Europe.

ii In Poland, the share of agriculture is by far the highest in the least developed economically voivodeships of eastern Poland, while in Ukraine in the western and southern oblasts of the country. This is because both in Poland and Ukraine, these regions are the least urbanized.

iii The industrial sector is best developed in central and western Poland, while in Ukraine in the oblasts of eastern Ukraine (Donbas and Kharkiv) and in central Ukraine (Dnieper).

iv The spatial differentiation of the percentage of gross value added generated in construction in both Poland and Ukraine is much smaller 


\section{Katarzyna Filipowicz et al.}

than the differentiation of similar percentages in other sectors of the economy. In Poland, these percentages were between $6.8 \%$ in the Mazowieckie Voivodeship and $8.1 \%$ in the voivodeships of central Poland, while in Ukraine between $2.8 \%$ in central Ukraine and $4.6 \%$ in the west of the country.

v The service sector in Poland is best developed in the Mazowieckie Voivodeship, while in Ukraine in its northern oblasts. This is mainly due to the fact that Warsaw is in the Mazowieckie Voivodeship and Kyiv in northern Ukraine, which are the administrative centers and economically the most developed cities in their respective countries.

vi In other groups of Polish voivodeships, the share of gross value added in services oscillated around $60 \%$, in Ukraine between $40.8 \%$ in central Ukraine and $62.2 \%$ in the coastal oblasts of southern Ukraine.

\section{Notes}

1 https://bdl.stat.gov.pl/BDL/start (access: 2019-12-30).

2 http://www.UKRSTAT.gov.ua/ (access: 2019-12-30).

3 In January 2004, the nominal exchange rate of the hryvnia against the euro was 6.183, while in December 2008 it was only 3.301 (www.exchangerate-euro.com/ currency/UAH-hryvnia-ukraine/). 